IZA DP No. 7915

A Balancing Act at Times of Austerity: Matching the Supply and Demand for Skills in the Greek Labour Market

Konstantinos Pouliakas

January 2014 


\title{
A Balancing Act at Times of Austerity: Matching the Supply and Demand for Skills in the Greek Labour Market
}

\author{
Konstantinos Pouliakas \\ CEDEFOP, \\ University of Aberdeen Business School and IZA
}

Discussion Paper No. 7915

January 2014

IZA

P.O. Box 7240

53072 Bonn

Germany

Phone: +49-228-3894-0

Fax: +49-228-3894-180

E-mail: iza@iza.org

Any opinions expressed here are those of the author(s) and not those of IZA. Research published in this series may include views on policy, but the institute itself takes no institutional policy positions. The IZA research network is committed to the IZA Guiding Principles of Research Integrity.

The Institute for the Study of Labor (IZA) in Bonn is a local and virtual international research center and a place of communication between science, politics and business. IZA is an independent nonprofit organization supported by Deutsche Post Foundation. The center is associated with the University of Bonn and offers a stimulating research environment through its international network, workshops and conferences, data service, project support, research visits and doctoral program. IZA engages in (i) original and internationally competitive research in all fields of labor economics, (ii) development of policy concepts, and (iii) dissemination of research results and concepts to the interested public.

IZA Discussion Papers often represent preliminary work and are circulated to encourage discussion. Citation of such a paper should account for its provisional character. A revised version may be available directly from the author. 


\section{ABSTRACT}

\section{A Balancing Act at Times of Austerity: Matching the Supply and Demand for Skills in the Greek Labour Market}

This paper provides an evidence-based assessment of the current situation prevailing in the Greek market for skills and jobs. The synthesis of available skills intelligence for Greece, the country most severely affected by the global economic crisis of 2008 , is crucial as it is currently faced with tough decisions regarding the allocation of limited resources in the face of economic austerity. The paper engages in a comparative overview of Greece's performance on flagship Europe 2020 indicators on education and employment in relation to the EU. An empirical analysis of the incidence and determinants of skill mismatches in the Greek and EU job markets is also undertaken, using data from several European data sources. It is argued that a stronger vocational education and training pillar may constitute a valuable option for strengthening the links between the initial educational system and the labour market in Greece. But tackling skill mismatch requires skill development and skill utilization policies in the workplace. A stronger commitment to enhancing the skill content of jobs by employers via the adoption of high performance workplace practices, investment in continuous training, less reliance on casual labour and policies to support small and mediumsized enterprises in the war for talent are necessary if Greece is to make the most of its rich skills reserves.

JEL Classification: $\quad$ C25, I29, J11, J20, J24, J69

Keywords: skills, skill mismatch, Greece, vocational education and training, overeducation, shortages

Corresponding author:

Konstantinos Pouliakas

CEDEFOP

Europe 123

Thessaloniki (Pylaia) 57001

Greece

E-mail: Konstantinos.Pouliakas@cedefop.europa.eu

\footnotetext{
* The opinions expressed in this paper are solely those of the author and do not represent the official position and views of the European Centre for the Development of Vocational Training (CEDEFOP).
} 


\section{INTRODUCTION}

At the end of 2013 Greece will be undergoing its fifth consecutive year of recession, its level of GDP will have shrunk by more than a quarter relative to 2009 and the total level of employment will have contracted by $17 \%$ in the space of just four years (2008-2012). The collapse in the level of aggregate demand in the country has resulted in an astounding increase in the number of people in unemployment, from about 350.000 people (corresponding to an unemployment rate of about $8 \%$ ) in 2007 to more than 1.4 million individuals (27\%) in the Fall of 2013. The youth unemployment rate stood at the historically high $55.3 \%$ in 2012 , the largest rate in the EU according to Eurostat figures. Wages and living standards have been squeezed at times of austerity, resulting in $31 \%$ of the Greek population at risk of poverty or social exclusion. The share of people (aged 18-59) living in jobless households has gone up from $7.5 \%$ in 2008 to $13.7 \%$ by 2011 and an additional $6.8 \%$ of households have become unable to make ends meet in the past five years. To modern Greeks the current situation has an eerie resemblance to the ruins of its ancient temples, the ruins today being the foundations of the economic and societal fabric on which the modern post-1974 democracy was built on.

The debt crisis, and subsequent economic recession, that began in Greece in 2009, following the Great Financial Recession that shocked the world a year earlier, has exposed, and worsened, a series of structural weaknesses that were present in the Greek economy. These weaknesses were to be found in key pillars of the Greek economic and social infrastructure, one of which was the divide between its education and training system and the labour market. While there is little room for doubt that the massive unemployment rates experienced in Greece today are a reflection of ineffective aggregate demand and past macroeconomic imbalances, it also stands to reason that the road to economic recovery will require a sound long-term planning and restructuring of its skill creation and skill utilization systems. Indeed, the worlds of education and training and of the labour market in Greece have for a long time, too long, acted as rival 
suitors of Penelope, refusing to interact with one another and to pursue a common goal of enhancing the employability of graduates in jobs that can fully exploit and reward their human capital potential.

The aim of this paper is to provide an evidence-based assessment of the current situation prevailing in the Greek market for skills and jobs. The synthesis and provision of recent skills intelligence for Greece, the country most severely affected by the global economic crisis of 2008, is important as the Greek government is currently undergoing massive restructuring efforts and is faced with tough decisions regarding the allocation of limited resources in the face of fiscal austerity. Understanding the nature and factors related to the poor matching between the country's education and training system and the needs of its labour market may, thus, inform the design of better skills and employment policies.

The structure of the remainder of the paper is as follows. Section 2 reviews past evidence on the inelasticities and pathogeneses present in the Greek skills and job markets. Section 3 engages in a descriptive overview of key Europe 2020 indicators that describe the current and anticipated trends of skill supply and skill demand in the country. Section 4 contains an in-depth empirical analysis of the incidence and determinants of skill mismatches in the Greek labour market. Section 5 assesses the recent evidence on the effectiveness of vocational education and training (VET) in the country, given the widespread attention that VET has received in in the recent EU policy discourse as a valuable tool for combating skill mismatch. Section 6 evaluates the state of play regarding the skill intensity of jobs in Greece in relation to the EU. Finally, section 7 concludes.

\section{THE INELASTICITY OF EDUCATION AND TRAINING IN GREECE}

In the years preceding the current economic crisis, several authors had issued warnings about the inelasticity of the Greek education and training system, specifically in terms of its inability to align with the needs of the labour market and of society. Patrinos (1997) had already estimated 
in the mid-1990s that about $16 \%$ of the Greek workforce was overeducated. Dolton and Marcenaro-Gutierrez (2009) also showed, using comparable data from the European Community Household Surveys (ECHP), that Greece had one of the highest overeducation rates amongst EU member states in the 1990s. Livanos (2010) had furthermore identified the relation between higher education and the labour market in Greece as the "weakest link".

Some had attributed this inefficiency to the strong orientation of the educational process to the demands of the once dominant public sector in Greece, with many talented youth being allured by the prospect of landing an attractive public sector job (Kanellopoulos et al., 2003). Another sociological explanation had been based on the strong inclination of Greek families to invest in the higher education of their children for reasons that were sometimes unrelated to the employment motive, such as the acquisition of greater status in society. In some cases this has resulted in a greater propensity by young Greeks to study specific occupations (relative to the EU average), either because of greater prestige (e.g. law, medicine) or in search of greater security and non-monetary amenities (e.g. careers in the public sector, including the army and education sector). The skewed distribution of educational choices of students is believed to have been facilitated by factors such as the zero direct cost of education and from the erroneous expectations of families about the future prospects of such fields (Psacharopoulos, 2003).

The lack of attractiveness of the vocational education and training (VET) system in Greece had been identified as a further culprit (CEDEFOP, 2003). In particular, the greater tendency of young Greek students to pursue education that is mostly of an academic rather than of a technical orientation has been linked to the poor infrastructure of the vocational education and training stream in the country, to the fact that it is primarily school-based and, generally, to the poor employment and income prospects of graduates from technical schools (Mitrakos et al., 2010; Livanos and Pouliakas, 2011). All of the aforementioned factors have been correlated with the long-term poor image of the VET sector in the country. 
Other authors had highlighted that the increasing deregulation of employment laws and flexible labour market policies had resulted in the deepening of segmentation in the Greek job market. This is evidenced by the high share of involuntary take-up of atypical and sometimes informal contractual arrangements among (mainly young) Greek workers. These precarious employment contracts have been associated with jobs that offer low pay, minimal skill requirements and an absence of career development opportunities, all of which are associated with significantly lower job quality and job satisfaction relative to those at the upper tier of the labour market (Pouliakas and Theodossiou, 2005). Karamessini (2010) has also shown that a significant share of Greek university graduates who engage in job mobility at the early stages of their careers get trapped involuntarily at the lower end of the job market.

Finally, some of the distinctive characteristics of the Southern European labour market model have been noted, such as the tendency of individuals to engage in protracted job searches based heavily on informal contact methods. This is in itself partially an outcome of the low job mobility of individuals due to close family ties and high rates of private home ownership (Karamessini, 2008).

\section{SKILL SUPPLY AND DEMAND IN GREECE}

\subsection{Trends in skill supply}

Despite the fact that Greece traditionally has one of the lowest ratios of government expenditure on education to GDP in the EU, and is characterized by a markedly low incidence of early childhood education (see Table 1), the country has made significant progress in recent decades in terms of investing in the skills of its population. Although as much as a third (33\%) of the active Greek population are graduates from primary or lower secondary schools (Figure 1), an incidence that exceeds the EU average by about 10 percentage points, this is mainly an 
reflection of the historically low educational attainment of older cohorts. ${ }^{1}$ The strong commitment of the Greek population towards the educational process is evident by the fact that the share of young individuals (aged 18-24) who are enrolled in education or who have graduated from school with at least an upper secondary degree is higher than the EU average. Greece has also made significant progress in terms of mitigating the phenomenon of early school leaving in recent years, though recent anecdotal evidence points to a deteriorating trend as a result of the economic crisis.

\section{[INSERT TABLE 1 ABOUT HERE]}

At the same time, the upskilling of the Greek population during the past decade (2000-2010) is observed by the growth in the number of graduates from tertiary education. Although the share of tertiary educational attainment in Greece lags behind the EU average, the proportion of the active population that possesses a tertiary education degree has risen over the past decade by about 7 percentage points. A distinctive feature of the Greek reality is that a sizeable proportion of the country's tertiary education graduates undergo their studies in a foreign country, though this trend has slowed down in recent years. Relative to other EU member states, a greater share of these university graduates also tend to study disciplines related to science and engineering, while the opposite is true for subjects related to Health and Welfare.

The projections of anticipated labour supply in Greece and in the EU (see Figure 1) further confirm that the process of educational upgrading in Greece is likely to continue unabated in the forthcoming decade. ${ }^{2}$ By the year $2020,76 \%$ of the active population is likely to possess at least an upper secondary education, compared to $67 \%$ in 2010. Furthermore, about 1 in 3 economically active individuals will be in possession of a tertiary education degree. The current and expected massification of higher education has therefore called into question the extent to

\footnotetext{
${ }^{1}$ Indeed, the share of low-skilled graduates (i.e. with an educational attainment below lower secondary education) drops to $24 \%$ when restricting the sample to include only individuals aged 25-39.

${ }^{2}$ These projections are generated by the pan-European model of the European Centre for the Development of Vocational Training (CEDEFOP, 2012b) on the basis of the historical trends of growth in the active population.
} 
which graduates from higher education institutes will be able to sustain their positive employment prospects in the Greek labor market of the future (Mitrakos et al., 2010, p. 31). Nevertheless, it is worth pointing out that despite the rising levels of educational attainment, Greece will still have a higher percentage (23\%) of low-skilled people (i.e. graduates of primary or lower secondary school) compared to the EU average by 2020 .

\section{[INSERT FIGURE 1 ABOUT HERE]}

Associated with this argument are concerns regarding the quality of the education received by graduates from Greek schools and the low levels of skills possessed by the country's adult workforce. This is reflected by the higher share of low achievers in the well-known PISA test scores of literacy in reading, mathematics and science in Greece than in the EU. Perhaps of greater policy concern is the fact that the performance of young Greek pupils at the latest round of PISA tests (2013) fell relative to those in 2009, only one of three EU countries where the number of students with low results increased over the last four years. Moreover, adults in Greece tend to rank lower than in other EU member states in terms of the possession of high ICT skills. Of additional concern is the very low investment of the country in the process of lifelong learning, crucial for updating the skills of its adult population. With only $3 \%$ of individuals aged 25-64 participating in formal or non-formal learning, and $20 \%$ in informal learning, the ability of the Greek workforce to adapt to structural change and to the changing requirements of the economy and society appears to be significantly lower relative to some of its EU counterparts.

\subsection{Trends in skill demand}

In the years prior to the global economic crisis of 2008, the demand for skills in Greece mirrored the average trend in the European Union. During these years the country experienced a steady contraction in the primary sector of the economy (e.g. agricultural sector) and stagnation in the manufacturing sector. At the same time the sectors of economic activity that grew the most in 
terms of employment were those primarily associated with the public sector (e.g. public administration, education, health and social work, other community and social services), while the real estate and construction sectors also experienced positive growth.

Associated with these structural trends was an increasing demand for individuals who possessed higher educational qualifications and a corresponding decline in demand for lowereducated individuals (see Figure 2). In particular, individuals with a tertiary education degree increased their share in the total pool of employment by $42 \%$, which exceeded the EU average of $30 \%$. This strong demand for higher educated labour was also a reflection of the faster rates of economic growth experienced by the country in the first half of the decade relative to its EU neighbours.

\section{[INSERT FIGURE 2 ABOUT HERE]}

The robust employment prospects of individuals with higher-level academic credentials during the time period 2000-2007 is mirrored by the greater employment of managers (11\%), professionals (35\%) and technician and associate professionals (43\%) (see Figure 3), which tended to be higher in Greece than in the EU. ${ }^{3}$ The declining employment pattern in the medium rungs of the occupational distribution and the robust growth of elementary jobs, the so-called polarization phenomenon, was also evident yet somewhat muted in the case of Greece. This was due to positive employment growth taking place in skilled-non manual and manual occupations. There was however a notably bigger increase in demand for workers in elementary jobs and for service and market sales workers.

\section{[INSERT FIGURE 3 ABOUT HERE]}

Several authors have shown further that the private rates of return to education in Greece have been positive since the 1990s. In particular, it has been found that in the period 2004-2007 tertiary education graduates in Greece had a lower probability of joblessness and were recipients

\footnotetext{
${ }^{3}$ In the EU there was a corresponding increase in employment in the order of $15 \%$ for managers, $20 \%$ for professionals and $21 \%$ for technicians and associate professionals.
} 
of higher wage premiums compared to those with lower qualifications (Cholezas et al., 2010). ${ }^{4}$ Significant differences in the returns to education to different subjects or field of study have also been estimated, with graduates from engineering, ICT and medicine faring the best prospects and those from the Arts and Humanities the worst (Mitrakos et al., 2010; Livanos and Pouliakas, 2011). More recently, it has been shown that during the initial years of the economic recession (2009-2011), the relative difference in earnings between tertiary and secondary education graduates has widened (OECD, 2013).

The robust demand for people with higher qualifications in Greece became increasingly apparent during the years in which the economic crisis unfolded (2008-2012). In this period of economic contraction, and in spite of the marked squeeze in aggregate demand, individuals in possession of tertiary qualifications increased their share of employment by $3 \%$ (see Figure 2 ). This increase was lower than the corresponding rise of $17 \%$ observed in the EU as a whole, yet it is testament to the fact that a university degree provided a shield of protection in Greece at a time when the employment pool was rapidly shrinking.

\section{[INSERT TABLE 2 ABOUT HERE]}

Despite the evidence of steady or slightly rising demand for tertiary education graduates, it is worth noticing that a significant share of the recent labour market demand manifested in the take-up of involuntary part-time contracts. In addition, about $50 \%$ of the new hirings that took place in 2011 (measured by individuals with job tenure of less than 3 months) found jobs as service and shop and market sales workers and in elementary posts. $14 \%$ of the new hires also found jobs as craftsmen and in related trades, $11 \%$ became clerks and another $10 \%$ found employment as professionals. ${ }^{5}$

\footnotetext{
${ }^{4}$ What has been more contentious, though, is the extent to which the positive returns to education have arisen as a result of a strong demand for skilled labour (in tune with skill-biased technological change), or whether they reflect the declining labour market prospects of workers at the lower tier of the job market (particularly in the private sector).

${ }^{5}$ The figures are based on the author's own analysis of microdata from the 2011 wave of the European Labour Force Survey (Eurostat contract no LFS/2010/29). The 2-digit occupations that experienced an above average growth in new hires in Greece in the year 2011 (i.e. above 2\%) were: Chief executives, senior officials and legislators; Hospitality, shop and related services managers; ICT professionals; Customer services clerks; Personal and protective services workers; Personal care workers;
} 
Furthermore, as can be seen in Table 3 below, there was strong labour demand in the agriculture, forestry and fishing sector during the recessionary period in Greece (2008-2012). In particular, while the share of new hires in this sector corresponded to $6 \%$ of the total new hires in 2008 , four years later it had risen to $10 \%$. This reflected the significant increase in the order of $13 \%$ in the numbers of newly hired workers in the primary sector during that 4 -year period. Other sectors which saw robust labour demand were the accommodation and food service sector and administrative and support service activities. In contrast, the share of new hires diminished in the construction and wholesale and retail trade sectors.

[INSERT TABLE 3 ABOUT HERE]

\section{SKILL IMBALANCES IN THE GREEK LABOUR MARKET}

\subsection{A chronic detachment of skill supply and demand}

An indicator of the chronic detachment between the Greek education system and the needs of its job market is the poor integration of young graduates into the labor market. According to the 2000 ad hoc module of the European Labour Force Survey (EULFS), which examined the entry of young graduates into the labour market, more than $36 \%$ of Greek graduates had remained unemployed after two years of leaving continuous education for the first time. This constituted the second highest rate (following Slovakia) among all countries surveyed. Using micro-data from a nation-wide survey conducted in 2005 to examine different transition strategies of Greek university graduates, Karamessini (2010) assessed the effectiveness of labour market integration several years following their graduation. She found that about $36 \%$ of university graduates belonging to the 1998-2000 cohort had not yet found stable employment 5-7 years after

Skilled agricultural workers; Skilled forestry, fishery and hunting workers; Extraction and building trades workers; Food processing, wood working, textile and other craft and related trades workers; Stationary plant and machine operators; Drivers and mobile-plant operators; Cleaners and helpers; Agricultural, fishery and forestry labourers; Labourers in mining, construction, manufacturing and transport; Food preparation assistants; Street and related sales and service workers; Refuse workers and other elementary service workers. 
completing their studies. $28 \%$ of those employed were also observed to be doing jobs not matching their field of study.

The significant disconnect between the worlds of education and of the labour market in Greece in the years preceding the economic crisis is also evident by the recent Eurostat ad hoc survey of school to work transition undertaken in 2009. According to this survey, the average time needed by young Greeks (aged 15-34) to find their first "significant" job was approximately 13.1 months, almost double the EU27 average. ${ }^{6}$ An astonishing $30.7 \%$ of young people also declared that they found their first significant job only after 4 years (ELSTAT, 2012).

Overall in Greece individuals with higher education degrees have been somewhat shielded from the threat of joblessness and have experienced higher employment rates relative to people with lower qualifications. However, as shown in Figure 4, a notable feature of the Greek economy during the past decade, one that stood in stark contrast to the trend observed in most advanced economies, was that this relative difference in unemployment rates was quite small. According to Eurostat data for the years 2000-2008, while a primary or lower secondary graduate in the EU had a 2.5-3 times greater risk of unemployment relative to tertiary education graduates, in Greece the relative risk ranged between 1.17-1.2.

\section{[INSERT FIGURE 4 ABOUT HERE]}

The Greek case differs markedly relative to the average EU experience in the sense that upper secondary and non-tertiary graduates (ISCED 3-4) traditionally constitute the group with the highest rate of unemployment (ranging between $9-15 \%$ in Greece as opposed to $7-10 \%$ in the EU). It is also apparent from Figure 4 that whereas individuals with medium-level qualifications

\footnotetext{
${ }^{6}$ The first significant job was defined in the 2009 ad hoc module of the EULFS survey as the first job found after the completion of an individual's highest level of qualification that lasted at least 3 months. The average time needed to find the first significant job refers to the sample of graduates who left the formal education system 5 years ago. This mean duration ranges from 15.1 months for individuals with a primary or lower secondary education, to 13.9 months for those with an upper secondary qualification to 12.2 for tertiary education graduates.

${ }^{7}$ For instance, the unemployment rate of primary or lower secondary graduates in the period 2000-2008 ranged between 8-10 percent in Greece, whilst the respective figure for tertiary graduates was approximately 7-8\%.
} 
in the EU maintained their relative employment position during the years of the economic crisis, in Greece the unemployment spread between lower/medium-qualified workers relative to tertiary education graduates widened. This is a reflection of the specific structural features of the Greek labour market, such as the tendency of employers to hire individuals with a university degree over medium-qualified graduates even in jobs that do not require a higher level of skills, but also the poor attractiveness of medium-qualified graduates from vocational schools and postsecondary non-tertiary institutions.

\section{[INSERT TABLE 4 ABOUT HERE]}

\subsection{Deteriorating imbalances in the Greek job market in the years of the economic crisis}

The stark growth in overall unemployment during the years of the crisis primarily affected individuals with lower and upper secondary degrees, mainly as a result of the collapse in demand in the sectors of construction (where there was a $48 \%$ decline in employment between the years 2008-2012), manufacturing (-33\%) and real estate (-34\%). However, (young) tertiary education graduates were also severely affected by the discouraging prospect of joblessness, as their unemployment rate rose by 11 percentage points in the space of five years, reaching a historically high level of $18 \%$. Nevertheless, it is still considerably lower than the $26-27 \%$ unemployment rates faced by individuals with lower qualifications. Another striking indication of the weakening employment prospects of young (aged 20-34) recently graduated Greek graduates (i.e. those who have left the education and training system no more than 3 years ago) is given by the steep decline, in the order of $25 \%$, in their employment rate (see Table 4 ). A significant issue of policy concern is the rising share of long-term unemployment, as this has severe implications for the structural ability of the economy to match skills with labour market needs once the economy recovers from its current recession.

In the years prior to the current economic crisis, there was already a significant share (about $18 \%$ ) of tertiary education graduates taking up jobs that are typically associated with lower skill 
demands (i.e. those classified as categories 4-9 in the international standard classification of occupations). In the year 2007 about $7 \%$ of tertiary education graduates were employed as clerks, $6 \%$ could be found in service and market sales jobs and another $5 \%$ were working in the primary sector, as craftsmen, machine operators or in elementary occupations. This pattern of rising skill or hiring requirements was relatively similar to the one observed in the EU, although there was a slightly stronger trend of hiring university graduates in service and market sales occupations in Greece as opposed to craftsmen and clerks in the EU.

In the years of the economic crisis the share of university graduates taking up non-graduate jobs rose from 18\% in 2007 to 24\% in 2012 in Greece (see Table 5). Most marked has been the fall in the share of employment of tertiary education graduates in managerial positions (from 9\% in 2007 to $5 \%$ in 2012) and in technical and associate professional jobs (from $17 \%$ to $13 \%$ ). At the same time the share of tertiary graduates who were employed in service and sales jobs rose from $6 \%$ to $11 \%$.

\section{[INSERT TABLE 5 ABOUT HERE]}

Such a trend is reflected in the most recent estimates of qualification mismatch in Europe by CEDEFOP (2012a), in which Greece is ranked at the top of the EU (along with Spain) in terms of the share of the employee workforce that is affected by qualification mismatch. During the past decade (2001-2011), 26\% of Greek employees (aged 25-64) were employed in an occupation that required a lower educational qualification than the one they possessed, namely they were over-qualified. ${ }^{8}$ This figure was significantly higher than the EU average overqualification rate of 15\%. Of course, as argued by McGuiness (2006) and CEDEFOP (2012a), being an over-qualified worker (in the sense that a worker has a higher qualification than what is typically required in his/her job) is imperfectly correlated with having higher or lower skills than needed to fulfill one's tasks in the job. Nevertheless, in the year 2010 about $47 \%$ of employed

\footnotetext{
${ }^{8}$ These figures have been calculated using microdata from the European Labour Force Survey (EULFS) (under Eurostat contract no LFS/2010/29). The so-called empirical method has been employed, namely a comparison of each individual's qualification with the most commonly observed (mode) qualification within his/her (2-digit) occupational group.
} 
Greeks also complained that they had skills to undertake more demanding duties in their jobs, the second highest rate of over-skilled workers in the EU (the average EU over-skilling rate being $32 \%){ }^{9}$

\subsection{Determinants of skill mismatch in the Greek job market}

\subsubsection{Factors related to qualification mismatch}

In order to identify the factors that are associated with the probability that employees are affected by qualification mismatch, in particular over-qualification, discrete choice models have been estimated using samples of adult employees in Greece and the EU from the 2011 wave of the European Labour Force Survey (EULFS). The probability of an individual being overqualified (a binary outcome) is modelled on the basis of a latent variable model, where it is assumed that an individual's unobserved propensity to be in a particular state of overqualification is determined by the equation

$$
m_{i}^{*}=\beta_{0}+\mathbf{x}_{i} \boldsymbol{\beta}+I_{i}+C_{i}+u_{i}, m=1\left[m^{*}>0\right]
$$

where $m$, individual $i$ 's mismatch status in the year 2011, takes the value one if $m^{*}>0$ and zero if $m^{*} \leq 0 . \mathbf{x}$ is a vector of explanatory variables, including demographic (gender, age group, native status), socioeconomic (participation in lifelong learning, multiple job-holding, labour force status in previous year) and job-related characteristics (firm size, job tenure, working hours, type of contract, supervisory duties) of the respondents, $I$ is a set of industry dummy variables, while $u \sim$ i.i.d $N\left(0, \sigma^{2}\right)$, the disturbance term, is assumed to be identically and independently normally distributed, homoscedastic and characterised by zero conditional independence $[\mathrm{E}(\mathrm{u} / \mathbf{x}=0)]$. The estimated parameters, $\beta$, denote the average effect of each explanatory variable on the conditional probability of a positive response i.e. $\mathrm{P}(m=1 \mid \mathbf{x})$. Countryspecific conditions (e.g. differences in labour market institutions and the business cycle) are

\footnotetext{
${ }^{9}$ These figures are based on the $5^{\text {th }}$ wave of the European Working Conditions survey (EWCS), carried out in 2010 by the European Foundation for the Improvement of Working and Living Conditions (Eurofound), which surveys a random sample of workers (employed and self-employed) in 34 countries about their working conditions and quality of working life.
} 
taken into account when the sample of all EU countries is used, via the inclusion in the empirical specification of country-specific dummies $(C)$.

Table 6 reports marginal effects, namely the change in the probability of an individual being vertically mismatched in relation to particular characteristics. The demography of Greek employees who are in a state of over-qualification tends to be similar to that of the average EU employee, namely young single workers, females and non-natives. However, some clear differences can be observed with regards to job characteristics. For instance, over-qualified Greek workers are more likely to be found in jobs with precarious contracts and more demanding working conditions (part-time jobs, temporary contracts, shift work, jobs with longer working hours, jobs that do not entail supervisory duties). Other things equal, Greek employees who were mainly unemployed in the past year are also found to have a $4 \%$ greater chance of being over-qualified, as opposed to a $1 \%$ average marginal effect for the EU. This is an indication that many formerly jobless Greek workers have been willing to accept jobs below their own qualification level in the face of the fierce competition for a job, as their bargaining power has been eroded. The economic sector or industry in which people are employed is also found to have a bigger influence on the likelihood of over-qualification in Greece relative to the EU.

\section{[INSERT TABLE 6 ABOUT HERE]}

Another important difference between the Greek and EU samples can be observed in relation to the participation of over-qualified workers in continuous education and training. While it is expected that over-qualified workers should be more likely to engage in continuous learning in order to facilitate their transition to a better matched job in the future, the fact that Greek overqualified workers are less likely to participate in further formal or non-formal learning is potentially a reflection of the poor training prospects offered by their jobs. 


\subsubsection{Factors related to company recruitment difficulties}

Despite the abundant supply of unemployed or over-qualified/over-skilled workers in Greece, $38 \%$ of employers complained in the year 2013 about difficulties in finding the right talent (Manpower, 2013). Such difficulties are apparent in both medium-skilled jobs (e.g. market sales, technicians, clerks and customer service) and in higher-skilled occupations (e.g. IT professionals, accountants and finance professionals, engineers).

In the European Company Survey (ECS) ${ }^{10}$ managers from a representative sample of enterprises in European countries were asked whether they had difficulties in finding staff to fill either their skilled and/or low-skilled/unskilled posts. Data from the most recent available wave of the ECS, carried out in 2009, revealed that approximately 35-36\% of Greek and EU firms faced difficulties in finding workers to fill their skilled posts. 6 out of 10 Greek firms in the construction sector and 4 out of 10 in the manufacturing, wholesale and retail trade and financial services sectors reported such difficulties in filling their skilled vacancies. By contrast, only about 2 out of 10 managers reported similar problems in attracting skilled staff in the nonmarketed services sector (e.g. education, health, public administration). The incidence of reported labour shortages, namely the availability of workers for filling low-skilled/unskilled jobs, was considerably smaller, with about $14 \%$ of employers facing difficulty in the wholesale and retail sector, $11 \%$ in manufacturing and only $3-5 \%$ in other sectors. ${ }^{11}$

To obtain a better understanding of the characteristics of firms which are more likely to report such hiring difficulties in both Greece and the EU, a multivariate regression analysis is employed. The ECS dataset contains a wealth of information on firm characteristics and human

\footnotetext{
${ }^{10}$ The ECS is a representative sample telephone survey carried out by the European Foundation for the Improvement of Working and Living Conditions (Eurofound). A special feature of the survey is that interviews take place with the manager responsible for human resources in the establishment and when possible with an employee representative. Three waves of the survey have taken place since 2004, covering issues regarding working time arrangements and work-life balance in European workplaces, different forms of labour market flexibility as well as accompanying human resource measures and the nature and quality of workplace social dialogue. The second survey took place in 2009, while the third wave took place in 2013 (but the results will only be publicly available at the end of 2014).

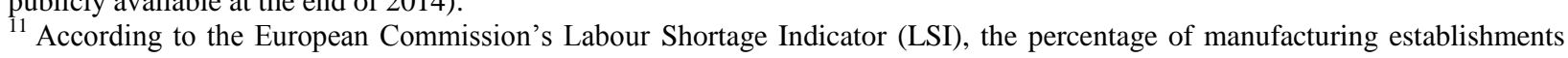
that considered the absence of labour to be a primary constraint to their production was not only historically lower in Greece than in other EU countries (2.5-3\% of Greek manufacturing firms faced shortages between 2007-2009, as opposed to an EU average of about $8 \%$ ), but also became almost negligible during the years of the crisis ( $0.5 \%$ in 2012 as opposed to about 5\% in the EU).
} 
resource management practices employed by firms. The probability of an establishment reporting difficulties in finding staff to fill their skilled vacancies a probit model has thus been estimated assuming the following latent specification

$$
s_{j}^{*}=\beta_{0}+\mathbf{x}_{j} \boldsymbol{\beta}+I_{j}+C_{j}+u_{j}, s=1\left[s^{*}>0\right]
$$

where $s^{*}$ describes the propensity of an manager to report that the establishment $j$ faces difficulties in hiring staff for their skilled posts $\left(s=1\right.$ if $\left.s^{*}>0\right) .{ }^{12} \mathbf{x}$ is a vector of determinants of the firms' perceived recruitment bottlenecks, including some basic characteristics (e.g. size of the establishment and changes in size in last 3 years, whether it is a single independent company or part of a wider organisation), the composition of the workforce in the firm (e.g. share of females, high-skilled and part-time workers) and a series of composite variables that proxy for the working conditions and human resource management practices of the establishment (see Annex 1). The latter are first principal components summarising whether the establishment relies on $(i)$ the employment of casual or atypical labour (e.g. temporary agency workers, fixed term employees, freelancers), (ii) the use of high performance workplace practices (e.g. teamwork, provision of continuing training and tracing of training needs, presence of health and safety committee, time flexibility), (iii) the adoption of variable pay and (iv) if employees are regularly required to work at atypical working hours. The specification also captures if the firm underwent important changes (e.g. work organisation, compensation schemes, restructuring) during the past 3 years. Finally, $I$ is a set of industry dummy variables and $C$ are country dummies. The error term $u \sim$ i.i.d $N\left(0, \sigma^{2}\right),[\mathrm{E}(\mathrm{u} / \mathbf{x}=0)]$, captures any unobserved factors related to whether firms report difficulties in filling their skilled vacancies.

\footnotetext{
${ }^{12}$ Equation (2) has also been estimated to detect the probability of firms reporting difficulties in finding labour to fill their low skilled/unskilled posts. However, due to space constraints, and given that such difficulties are confounded by high labour turnover, the results are not reported in the paper. They are however available upon request from the author.
} 
Table 7 reports marginal effects, namely the change in the probability of an establishment reporting hiring difficulties for skilled labour in relation to particular characteristics ${ }^{13}$. In contrast to the EU, Greek establishments in the hotels and restaurants and education sectors are found to be less likely (relative to manufacturing) to have difficulties in filling their skilled posts. In addition, although in the EU the human health and social work sector is found to be $4 \%$ more likely than the manufacturing sector to report recruitment impediments, in Greece there is limited evidence of reported skill bottlenecks in that sector.

Smaller-sized Greek firms are more likely to report difficulties in filling their skilled jobs. Greek firms that rely on the hiring of casual labour and those requesting from their employees to work at irregular hours also have a 6-7\% greater chance of reporting hiring bottlenecks for skilled personnel. Similar associations, though of a smaller magnitude, are observed in the EU, though hiring difficulties are also positively correlated with the provision of high performance workplace practices and the offer of variable pay. Managers in firms that experienced major changes in their processes and in the size of their workforce in previous years are also more likely to report recruitment problems for their skilled vacancies.

It is thus apparent that in the EU part of the reason for the reported obstacles to filling skilled jobs are the dynamic skill requirements of innovative establishments, whereas in Greece poor and atypical working arrangements are the primary culprits. Smaller sized firms, which are likely to be disadvantaged in their ability to compete in the outsider's market for talent, but also systematically fail to invest in the training of their existing workforce, are also found to be the most affected by an reported inability to fill their skilled vacancies. ${ }^{14}$

\footnotetext{
${ }^{13}$ As a robustness check, equation (2) has also been estimated using a multilevel random-intercept technique, which allows for a more parsimonious specification and the use of a flexible maximum likelihood estimator. The sign and statistical significance of the key variables of interest is confirmed for the EU sample, whereas it is also found that the standard deviation of the countryspecific random intercept is statistically significant $\left(\hat{\beta}_{0}=0.88, \operatorname{sd}\left(\hat{\beta}_{0}\right)=0.47, \operatorname{se}\left(\hat{\beta}_{0}\right)=0.07, C I=[0.36,0.63]\right)$. Estimates are available from the author upon request.

${ }^{14}$ According to the 2009 wave of the ECS, 50\% (57\%) of Greek (EU) establishments with 10-19 employees gave in the past year time-off from their normal duties to the employees in order to undertake further training activities. The corresponding figure is $71 \%$ (73\%) for those firms with 50-299 employees and 90\% (87\%) for those with a workforce in excess of 500.
} 
[INSERT TABLE 7 ABOUT HERE]

\section{STRENGHTENING VOCATIONAL EDUCATION AND TRAINING IN GREECE}

Figure 4 highlighted that an important issue of concern for Greece is the lower employability of its upper secondary and non-tertiary graduates, which is based, to a large extent, on the vocational education and training (VET) pillar of the system.

Mitrakos et al. (2010) confirm that in the years preceding the economic crisis the financial rates of return to education enjoyed by medium-qualified graduates from a general orientation lyceum were slightly higher than those from technical and vocational schools (yet most of these wage differences dissipate after a decade of work experience). Moreover, a special Eurobarometer survey, undertaken in 2011, revealed that Greeks generally have positive attitudes towards VET, with many respondents believing that this particular educational stream is closely linked to the needs of the labour market. However, lower perceptions regarding the quality of learning, inadequate access to modern equipment, an inability to pursue further studies and lack of career prospects are all likely to underlie the poor labour market outcomes of VET graduates. Furthermore, the easier access to VET, which tends to attract a lower quality applicant pool, may also explain why VET occupations are not as well regarded in Greek society as are academic studies.

\section{[INSERT TABLE 8 ABOUT HERE]}

The incidence of VET graduates in Greece is significantly lower than in other EU countries. The share of initial VET students in the total pool of young Greek adults (aged 25-34) with medium-level qualifications was recently reported to be less than two-thirds of the EU average (CEDEFOP, 2013). Specifically, according to the 2009 ad hoc module of the EU Labour Force Survey, only about $46 \%$ of all young adults with a medium-level educational attainment had enrolled in VET courses in Greece, while the respective percentage for the EU was $72 \%$ (see Figure 5). Furthermore, on the basis of the respondent's answers to the survey, the Greek VET 
system can be characterized as being mainly "school-based", as opposed to the strong dual VET systems in countries such as Germany, Denmark, Austria and Switzerland.

\section{[INSERT FIGURE 5 ABOUT HERE]}

Significant differences in the pathways of young students (aged 18-24) finishing mediumlevel education and training are observed between Greece and the EU. Greek students who complete upper secondary or post-secondary non-tertiary education from a VET school are less likely to continue with their studies ( $13 \%$ do so in Greece, in comparison to $27 \%$ in the EU) and have a greater likelihood of becoming unemployed or inactive (29\% in Greece as opposed to $19 \%$ in the EU). A greater share is nonetheless likely to enter the job market. ${ }^{15}$ Indeed, multivariate regression analysis confirms that in Greece, more so than in the EU, young VET graduates at the medium-education level are more likely to enjoy a faster school to work transition and to be employed relative to general orientation graduates (Table 9). ${ }^{16}$ However, while in the EU a VET orientation is associated with a lower probability of over-qualification, in Greece the likelihood of qualification mismatch is higher, reflecting the greater obstacles of job seekers in finding a suitable job.

\section{[INSERT TABLE 9 ABOUT HERE]}

On the basis of CEDEFOP's projections of skill demand and skill supply (2012b), approximately 1.4 million jobs will have to be replaced in Greece by 2020 , due to the gradual retirement of older workers from the labour force. Generally, by 2020 about $59 \%$ of all replacement needs in Greece will require non-manual (e.g. clerks, market services and sales) and manual skilled labour (e.g. skilled agricultural and fishery, craftsmen), an additional 7\% will rely on low-skilled workers filling elementary jobs and the remaining $34 \%$ will need individuals

\footnotetext{
${ }^{15}$ Specifically, the duration between leaving formal education and starting their first significant job (lasting more than 3 months) is smaller for medium-qualified graduates with a VET orientation relative to general education graduates. For instance, for $30 \%$ of general education graduates it takes more than 2 years to find their first significant job, in contrast to $22 \%$ for VET graduates. Furthermore, the former are also more likely to spend prolonged periods outside of work (71\% spend more than 2 years unemployed or inactive), as opposed to VET graduates (the corresponding figure is 54\%).

${ }^{16}$ In the case of tertiary education graduates, Karamessini (2010) shows further that continuous work experience during their undergraduate studies positively influences their odds of employment and of being in a well-paid job 5-7 years after graduation, as is the participation in formal traineeship schemes.
} 
capable of taking up high-skilled posts (e.g. managers, professionals, technicians and associate professionals). About 381.000 people will be required in the primary sector in the next decade due to the need to replace the cohort of workers that is retiring or withdrawing from the labour force. Similarly, about 403.000 people will have to be replaced in industries related to the transport and distribution sector. From the above figures it is thus evident that about two-thirds of all available job opportunities in Greece in coming years will be at the low- and mediumspectrum of the distribution of skill requirements.

CEDEFOP predicts that about $42 \%$ of the active Greek population is likely to possess a medium-level qualification by 2020 (see Figure 1). It is thus apparent that a potentially beneficial strategy for the Greek initial education and training system is to focus its attention towards strengthening the vocational component of learning at the upper secondary/non-tertiary level of the educational system.

\section{IMPROVING THE SKILL CONTENT OF JOBS}

A conventional wisdom is that the high rate of skill mismatch observed in Greece is a reflection of inefficiencies in the country's education and training system, which has failed to keep up with the rapid pace of the economy's rising skill demands and high rates of skill obsolescence in many occupations. For instance, more than a third of the Greek workforce (and 4 out of 10 employees in the EU) recently experienced new technologies and processes in their workplace that had an immediate impact on their working environment. There has also been a considerable increase in the average time that employees spend working with computers as part of their regular job tasks (see Table 10).

Even though the initial educational system has a crucial role to play in adequately preparing young individuals for their entry into the labour market by providing them with necessary foundation skills, the mitigation of skill mismatch in Greece, as in the EU, is largely dependent on the continuous efforts of employers and policymakers to efficiently utilize such skills and to 
stimulate the continuous development of work-based skills over their lifetime. As argued by CEDEFOP (2012a), the mitigation of skill mismatch, particularly of over-qualification and overskilling, is intrinsically dependent on the existence of challenging workplaces, which do not only update the available stock of knowledge and skills possessed by individuals but also exploit and continually raise the skills of individuals by enriching the skill content of their jobs.

Nevertheless, Table 10 reveals that the jobs held by Greek employees appear to be characterized by significantly lower skill requirements relative to those held by the average EU worker. Worryingly, these skill requirements have failed to exhibit any clear upward trend since the second half of the past decade. Several indicators of job complexity and of learning opportunities in the workplace reveal that the nature of task variety and discretion, the ability to learn new things or to apply one's own ideas at work and the incidence of continuous job training have followed a consistent downward tendency in Greece during the second half of the previous decade.

\section{[INSERT TABLE 10 ABOUT HERE]}

\section{CONCLUSIONS}

In the past five years the Greek economy and society have been faced with a Great Depression. About a third of the labour force has been in unemployment or underemployment, the entire fabric of the production structure that prevailed in the pre-crisis era has been compromised and a significant share of the population has been confronted with rising poverty and social exclusion. Furthermore, an entire cohort of young Greek graduates has entered into a depressed labour market, struggling to find a job. Moreover, in the year 2011 Greece was not only the EU country with the highest youth unemployment rate, but it was also characterized by the highest incidence of individuals employed in jobs that are an unsuitable fit for their education and skills.

While the most important policy objective for Greece is to quickly resume to positive rates of job creation, the economic crisis has also served as a useful impetus for reassessing and 
correcting many of the past pathogeneses that have affected the country in the run-up to the recession. Problems and inertia, such as a lack of connection between the education and training system and the job market, the inefficiency of its vocational education system, lack of trust and of transparency between relevant stakeholders and, most importantly, the lack of time consistency in educational policies, will have to be overcome if Greece is to ensure that it will have a modern and dynamic educational system that is in tune with the needs of the knowledge economy and society.

This paper has provided evidence that a stronger vocational education and training pillar may constitute a valuable option for strengthening the links between the initial educational system and the labour market in Greece. But tackling skill mismatch in the country requires skill development and skill utilization policies over the lifecycle, which are best suited to take place within the workplace. A stronger commitment to enhancing the skill content of jobs by employers, via the adoption of high performance workplace practices, investment in continuous training, less reliance on casual labour and policies to support small and medium-sized enterprises are necessary if Greece is to make the most of its rich skills reserves that are currently being wasted.

\section{REFERENCES}

CEDEFOP (2003), Vocational Education and Training in Greece, Cedefop Panorama Series: No 59, Luxembourg: Office for Official Publications of the European Communities.

CEDEFOP (2012a), 'The Skill Mismatch Challenge in Europe', in: European Commission (2012), Employment and Social Developments in Europe 2012, Luxembourg: Office for Official Publications of the European Communities.

CEDEFOP (2012b), Future skills supply and demand in Europe: Forecast 2012, Luxembourg: Office for Official Publications of the European Communities (Cedefop Research Paper No 21). 
CEDEFOP (2013), Labour market outcomes of vocational education in Europe: Evidence from the European Union Labour Force Survey, Research paper No. 32, Luxembourg: Publications Office of the European Union.

Cholezas, I., Mitrakos, T. and Tsakloglou, P. (2010), "Determinants of youth unemployment in Greece, with emphasis on tertiary education graduates", Economic Bulletin of the Bank of Greece 33, 2010, pp. 23-68.

Dolton, P. and Marcenaro-Gutierrez, O. (2009), “Overeducation Across Europe” in: Dolton, P., Asplund, R. and Barth, E. (eds.), Education and Inequality Across Europe, Ch. 4, Cheltenham, Northampton, Mass: Edward Elgar Publishing.

European Commission (2010), "Youth and segmentation in EU labour markets", Ch.3, in Employment in Europe 2010, Luxembourg: Office for Official Publications of the European Communities.

European Commission (2011), Attitudes towards vocational education and training, Special Eurobarometer 369, http://ec.europa.eu/public_opinion/index_en.htm

ELSTAT (Hellenic statistical authority) (2012), http://www.statistics.gr/portal/page/portal/ESYE/PAGEthemes?p_param $=A 0102 \&$ r_param $=S J O 19 \& y \_$param $=2009 \_00 \&$ mytabs $=0$ [assessed: 10.07.2013]

Kanellopoulos, C.N., Mitrakos, T. and Mavromaras, K.G. (2003), Education and Labour Market, Center for Planning and Economic Research, Scientific Studies no. 50: Athens (in Greek).

Karamessini (2008), "Still a distinctive southern European employment model”. Industrial Relations Journal, 39 (6).

Karamessini, M. (2010), "Transition strategies and labour market integration of Greek university graduates", GreeSE paper No. 32, Hellenic Observatory papers on Greece and Southest Europe, February.

Livanos, I. (2010), “The Relationship Between Higher Education and the Labour Market in Greece: The Weakest Link?", Higher Education, 60, 473-489.

Livanos, 1. and Pouliakas, K. (2011) 'Wage Returns to University Disciplines in Greece: Are Greek Higher Education Degrees Trojan Horses?', Education Economics, vol. 19, no. 4, pp. 411-445.

Manpower (2013), Talent shortage survey: Research results, available at: $\underline{w w w . m a n p o w e r . c o . u k}$

McGuinness, S. (2006), “Overeducation in the Labour Market”, Journal of Economic Surveys, Vol. 20, No 3, pp. 387-418.

Mitrakos, T., Tsakloglou, P. and Cholezas, I. (2010), "Determinants of wages in Greece, with emphasis on earnings of tertiary education graduates", Bank of Greece Economic Bulletin, Vol. 34 (Sep), pp. 7-42.

OECD (2013), Education at a Glance 2013, Paris. 
Patrinos, H. (1997), “Overeducation in Greece”, International Review of Education, Vol. 43, No. 2/3, pp. 203223.

Pouliakas, K. and Theodossiou, I. (2005), "Socio-Economic Differences in the Perceived Quality of High and Low-Paid Jobs in Greece", Bank of Greece Economic Bulletin, Vol. 24, January, p. 91-132.

Psacharopoulos, G. (2003), "The social cost of an outdated law: Article 16 of the Greek constitution", European Journal of Law and Economics, Vol. 16, pp. 123-137. 
Figure 1 Active population by highest level of educational attainment, age 25-65, Greece \& EU27, 2000-2020
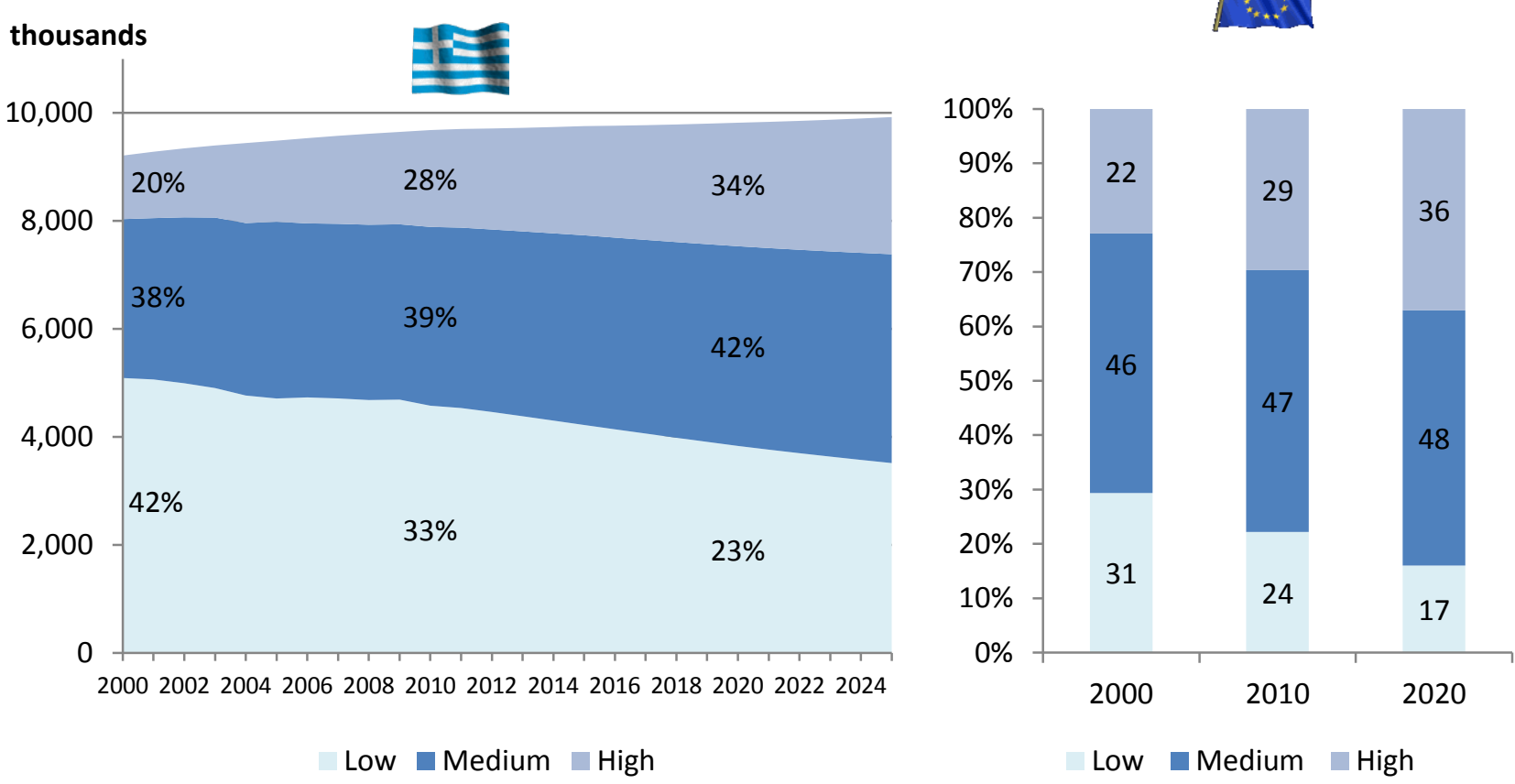

Source: Eurostat; Cedefop forecasting model of skill supply and demand; Low education: ISCED 0-2; Medium education: ISCED 3-4; High Education: ISCED 5-6.

Table 1 Labour Supply - Education and Training Indicators, Greece and EU

\begin{tabular}{|c|c|c|c|c|c|c|}
\hline \multirow[t]{2}{*}{ Indicator } & \multicolumn{3}{|c|}{$G R$} & \multicolumn{3}{|c|}{ EU27 } \\
\hline & $2012(\%)$ & $\begin{array}{c}2007-2012 \\
(\%)\end{array}$ & $\begin{array}{c}2000-2012 \\
(\%)\end{array}$ & $2012(\%)$ & $\begin{array}{c}2007-2012 \\
(\%)\end{array}$ & $\begin{array}{c}2000-2012 \\
(\%)\end{array}$ \\
\hline $\begin{array}{l}\text { Investment in early } \\
\text { education }\end{array}$ & & & & & & \\
\hline $\begin{array}{l}\text { Investment in education } \\
\text { and training }- \text { Public } \\
\text { spending on education, } \\
\% \text { of GDP }\end{array}$ & 4.1 & 0.2 & 0.7 & 5.3 & 0.2 & 0.4 \\
\hline $\begin{array}{l}\text { Participation in early } \\
\text { childhood education ( } 4 \\
\text { year old - year before } \\
\text { start of compulsory } \\
\text { primary) }\end{array}$ & $73.5^{\S}$ & 5.3 & 4.2 & $92.4^{\S}$ & 2.1 & 7.2 \\
\hline $\begin{array}{l}\text { Students enrolled aged } \\
15-24 \text { as \% of } \\
\text { corresponding age } \\
\text { population (ISCED 1-6) }\end{array}$ & $63.2^{\S}$ & 3.1 & 9.6 & $61^{\S}$ & 1.5 & 6.2 \\
\hline $\begin{array}{l}\text { Early leavers from } \\
\text { education and training } \\
\text { (age 18-24) }(\%)\end{array}$ & 11.4 & -3.2 & -6.8 & $12.8^{p}$ & $-2.2^{\mathrm{p}}$ & $-4.8^{p}$ \\
\hline $\begin{array}{l}\text { Population with at least } \\
\text { upper secondary } \\
\text { attainment (\%) (age 20- } \\
24)\end{array}$ & 85.4 & 3.3 & 6.2 & 80.2 & 2.1 & 3.6 \\
\hline
\end{tabular}




\begin{tabular}{|c|c|c|c|c|c|c|}
\hline - Reading & $21.3^{*}$ & $-6.4^{ \pm}$ & -3.1 & $19.6^{*}$ & $-3.0^{ \pm}$ & -0.2 \\
\hline - Maths & $30.3^{*}$ & $-2^{ \pm}$ & - & $22.2^{*}$ & $-1.8^{ \pm}$ & - \\
\hline - Science & $25.3^{*}$ & $1.3^{ \pm}$ & - & $17.7^{*}$ & $-2.6^{ \pm}$ & - \\
\hline \multicolumn{7}{|c|}{ Tertiary students by field of study, as $\%$ of all fields ${ }^{s}$} \\
\hline - Education and training & 5.9 & 0 & -1 & 8.1 & -1 & -1 \\
\hline - Humanities and art & 12.8 & -1 & -1 & 12.5 & -1 & 0 \\
\hline $\begin{array}{l}\text { - Social science, business } \\
\text { and law }\end{array}$ & 33.2 & 0 & 0 & 34.7 & 0 & 0 \\
\hline $\begin{array}{l}\text { - Maths, science and } \\
\text { technology }\end{array}$ & 13.8 & 0 & -3 & 10.2 & 0 & 0 \\
\hline $\begin{array}{l}\text { - Engineering, } \\
\text { manufacturing and } \\
\text { construction }\end{array}$ & 18.4 & 1 & 4 & 14.7 & 0 & -1 \\
\hline $\begin{array}{l}\text { - Agriculture and } \\
\text { veterinary science }\end{array}$ & 5.0 & -1 & -1 & 1.8 & 0 & -1 \\
\hline - Health and welfare & 8.1 & -2 & 1 & 13.9 & 1 & 3 \\
\hline - Services & 2.7 & 0 & -2 & 4.1 & 0 & 1 \\
\hline $\begin{array}{l}\text { Percentage of all tertiary } \\
\text { students (ISCED 5-6) } \\
\text { enrolled outside their } \\
\text { country of origin }\end{array}$ & $5.4^{\S}$ & -0.4 & -7.0 & $3.1^{\S}$ & 0.4 & 1.0 \\
\hline \multicolumn{7}{|l|}{ Skill supply of adults } \\
\hline $\begin{array}{l}\text { Young people aged 18- } \\
24 \text { not in employment, } \\
\text { and not in any education } \\
\text { or training (NEET) }(\%)\end{array}$ & 28.4 & 12.7 & 5.8 & $17^{\mathrm{p}}$ & 2.9 & 0.1 \\
\hline $\begin{array}{l}\text { Tertiary educational } \\
\text { attainment (age } 30-34)\end{array}$ & 30.9 & 4.7 & 5.5 & 35.8 & 5.8 & 13.4 \\
\hline $\begin{array}{l}\text { Adult participation in } \\
\text { lifelong learning (age } \\
\text { 25-64) }\end{array}$ & 2.9 & 0.8 & 1.8 & 9 & -0.3 & 1.9 \\
\hline $\begin{array}{l}\text { ICT skills - Percentage } \\
\text { of individuals aged 16- } \\
74 \text { with high computer } \\
\text { skills }\end{array}$ & 24 & 9 & - & 26 & 3 & - \\
\hline & & & & & & \\
\hline
\end{tabular}

Sources: Eurostat/EU Labour Force Survey (EULFS); Eurostat/UOE: UNESCO-OECD-Eurostat data collection on education systems statistics; OECD PISA study 
Figure 2 Employment by highest level of education attained, 2000-2012, Greece and EU27

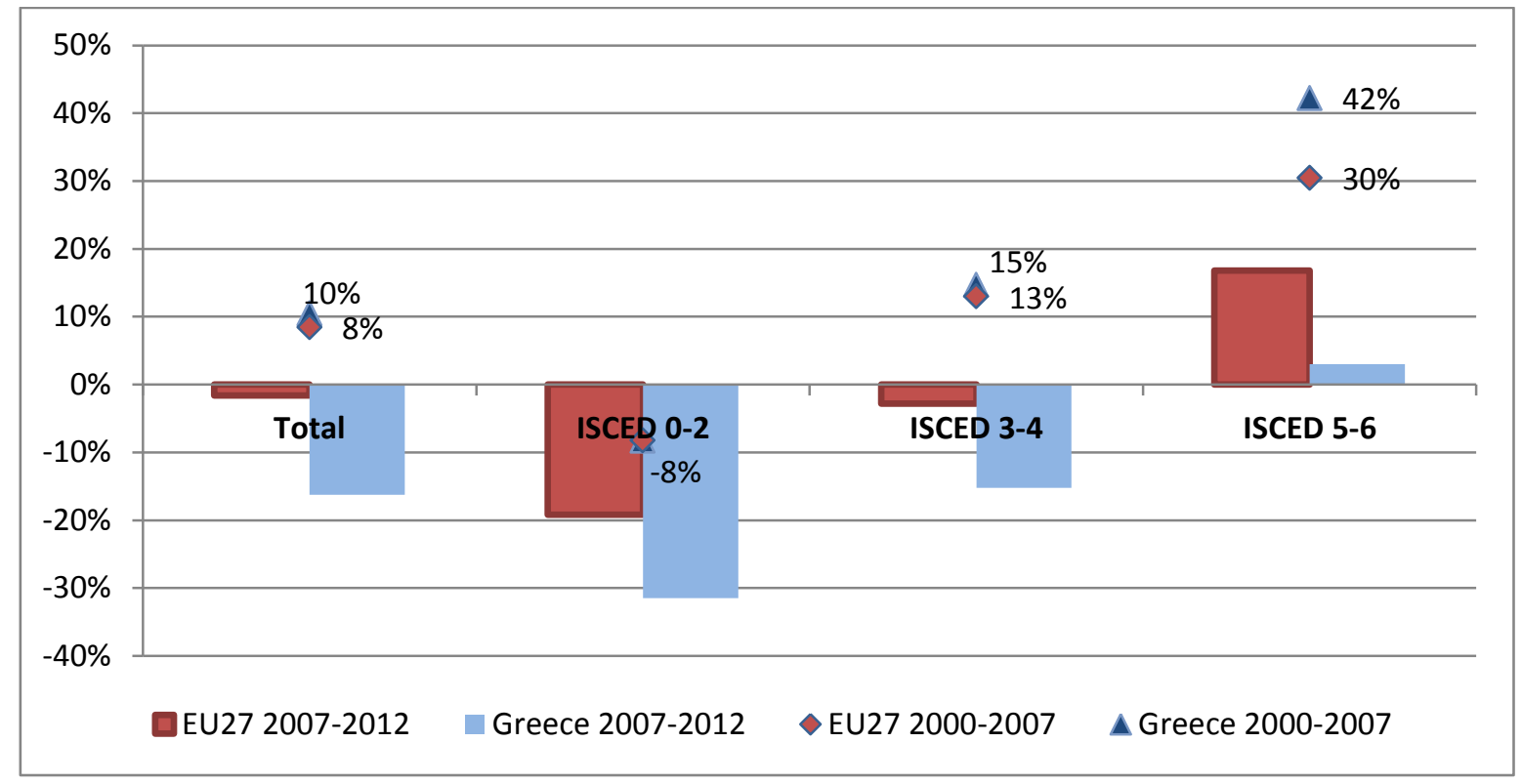

Source: Eurostat

Figure 3 Change in employment by broad occupational group, 2000-2010, Greece and EU27

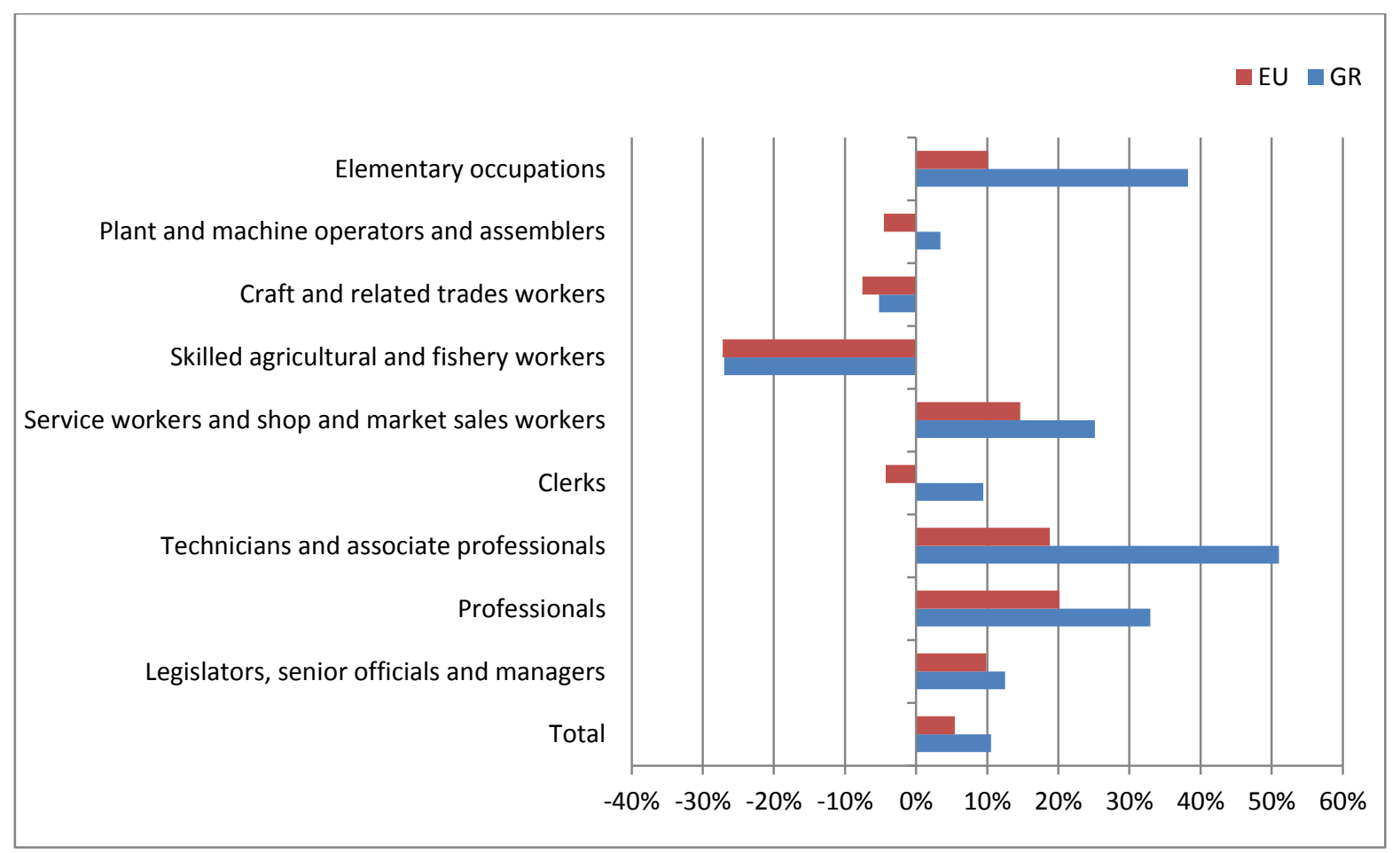

Source: Eurostat 
Table 2 Indicators of Labour Demand, Greece and EU27

\begin{tabular}{|c|c|c|c|c|c|c|}
\hline & \multicolumn{3}{|c|}{$G R$} & \multicolumn{3}{|c|}{$\boldsymbol{E U}$} \\
\hline Indicator & 2012 & $\begin{array}{c}\text { \% change } \\
2000- \\
2007\end{array}$ & $\begin{array}{c}\text { \% change } \\
2007- \\
2012\end{array}$ & 2012 & $\begin{array}{l}\% \text { change } \\
2000-2007\end{array}$ & $\begin{array}{l}\% \text { change } \\
2007-2012\end{array}$ \\
\hline $\begin{array}{l}\text { Employment level (age } \\
\text { 15-64; by broad } \\
\text { occupational group) }\end{array}$ & 3,763 & 10.0 & -17.0 & 216,059 & 8.0 & -1.0 \\
\hline $\begin{array}{l}\text { - Legislators, senior } \\
\text { officials and managers }\end{array}$ & 165.4 & 11.0 & -64.0 & 12,857 & 15.0 & -29.0 \\
\hline - Professionals & 703.1 & 35.0 & 8.0 & 39,356 & 20.0 & 33.0 \\
\hline $\begin{array}{l}\text { - Technicians and } \\
\text { associate professionals }\end{array}$ & 301.3 & 43.0 & -23.0 & 33,790 & 21.0 & -4.0 \\
\hline - Clerks & 377.4 & 10.0 & -25.0 & 21,111 & -2.0 & -9.0 \\
\hline $\begin{array}{l}\text { - Service workers and } \\
\text { shop and market sales } \\
\text { workers }\end{array}$ & 795.9 & 19.0 & 26.0 & 37,024 & 13.0 & 25.0 \\
\hline $\begin{array}{l}\text { - Skilled agricultural, } \\
\text { forestry and fishery } \\
\text { workers }\end{array}$ & 461.7 & -28.0 & -8.0 & 8,859 & -28.0 & -9.0 \\
\hline $\begin{array}{l}\text { - Craft and related trades } \\
\text { workers }\end{array}$ & 411.7 & 5.0 & -40.0 & 25,927 & -2.0 & -16.0 \\
\hline $\begin{array}{l}\text { - Plant and machine } \\
\text { operators and assemblers }\end{array}$ & 237.3 & 5.0 & -28.0 & 15,936 & 4.0 & -16.0 \\
\hline - Elementary occupations & 253 & 27.0 & -15.0 & 19,479 & 21.0 & -9 \\
\hline $\begin{array}{l}\text { Employment rate (age } \\
15-64 ; \text { by highest level } \\
\text { of education attained) }\end{array}$ & 51.3 & 2.5 & -10.1 & 64.2 & 3.2 & -1.1 \\
\hline $\begin{array}{l}\text { - Primary and lower } \\
\text { secondary }\end{array}$ & 41.0 & 3.0 & -11.3 & 44.0 & -0.3 & -4.5 \\
\hline - Upper secondary & 49.7 & 3.8 & -11.1 & 68.1 & 1.8 & -2.0 \\
\hline - Tertiary & 70.3 & 1.3 & -11.6 & 81.8 & 1.3 & -1.9 \\
\hline \multicolumn{7}{|l|}{ Type of employment } \\
\hline $\begin{array}{l}\text { Temporary employees } \\
\text { as \% of total number } \\
\text { of employees (age 15- } \\
64 \text { ) }\end{array}$ & 10.0 & -2.9 & -0.9 & 13.7 & 2.4 & -0.9 \\
\hline $\begin{array}{l}\text { Part-time employment } \\
\text { as } \% \text { of total } \\
\text { employment }\end{array}$ & 7.6 & 1.0 & 2.2 & 19.2 & 1.8 & 1.6 \\
\hline $\begin{array}{l}\text { Involuntary part-time } \\
\text { employment as \% of } \\
\text { total part-time } \\
\text { employment }\end{array}$ & 65.0 & -3.2 & 19.8 & 27.7 & $4.4^{\S}$ & 5.3 \\
\hline & & & & & & \\
\hline
\end{tabular}

Notes: §2001-2007

Source: Eurostat 
Table 3 Employment of new hires (less than 3 months) by industry, GR and EU27, 2008-12

\begin{tabular}{|c|c|c|c|c|}
\hline & \multicolumn{2}{|c|}{$\begin{array}{l}\% \text { change in employment } \\
\text { of new hires, } 2008-2012\end{array}$} & \multicolumn{2}{|c|}{$\begin{array}{c}\text { Change in share of new } \\
\text { hires in total employment of } \\
\text { new hires, } 2008-2012\end{array}$} \\
\hline & $G R$ & $E \boldsymbol{U}$ & $\boldsymbol{G R}$ & $\boldsymbol{E} \boldsymbol{U}$ \\
\hline Agriculture, forestry and fishing & $13 \%$ & $-9 \%$ & $4 \%$ & $0 \%$ \\
\hline Mining and quarrying & . & $-14 \%$ & . & $0 \%$ \\
\hline Manufacturing & $-34 \%$ & $-20 \%$ & $0 \%$ & $-1 \%$ \\
\hline $\begin{array}{l}\text { Electricity, gas, steam and air conditioning } \\
\text { supply }\end{array}$ & . & $6 \%$ & . & $0 \%$ \\
\hline $\begin{array}{l}\text { Water supply; sewerage, waste } \\
\text { management and remediation activities }\end{array}$ & . & $6 \%$ & . & $0 \%$ \\
\hline Construction & $-43 \%$ & $-23 \%$ & $-3 \%$ & $-1 \%$ \\
\hline $\begin{array}{l}\text { Wholesale and retail trade; repair of motor } \\
\text { vehicles and motorcycles }\end{array}$ & $-39 \%$ & $-12 \%$ & $-2 \%$ & $0 \%$ \\
\hline Transportation and storage & $-33 \%$ & $-11 \%$ & $0 \%$ & $0 \%$ \\
\hline $\begin{array}{l}\text { Accommodation and food service } \\
\text { activities }\end{array}$ & $-17 \%$ & $2 \%$ & $2 \%$ & $1 \%$ \\
\hline Information and communication & . & $-11 \%$ & . & $0 \%$ \\
\hline Financial and insurance activities & . & $-26 \%$ & . & $0 \%$ \\
\hline Real estate activities & . & $-7 \%$ & . & $0 \%$ \\
\hline $\begin{array}{l}\text { Professional, scientific and technical } \\
\text { activities }\end{array}$ & $-40 \%$ & $-9 \%$ & $-1 \%$ & $0 \%$ \\
\hline $\begin{array}{l}\text { Administrative and support service } \\
\text { activities }\end{array}$ & $71 \%$ & $-3 \%$ & $2 \%$ & $1 \%$ \\
\hline $\begin{array}{l}\text { Public administration and defence; } \\
\text { compulsory social security }\end{array}$ & $-9 \%$ & $-22 \%$ & $1 \%$ & $-1 \%$ \\
\hline Education & $-20 \%$ & $-5 \%$ & $0 \%$ & $0 \%$ \\
\hline Human health and social work activities & $-39 \%$ & $0 \%$ & $-1 \%$ & $1 \%$ \\
\hline Arts, entertainment and recreation & . & $-3 \%$ & $0 \%$ & $0 \%$ \\
\hline Other service activities & . & $-16 \%$ & . & $-1 \%$ \\
\hline Activities of households as employers & $-25 \%$ & $13 \%$ & $0 \%$ & $1 \%$ \\
\hline Total & $-26 \%$ & $-10 \%$ & & \\
\hline
\end{tabular}

Source: Eurostat, NACE Rev. 2, . = na 
Figure 4 Differences in unemployment rates by levels of educational attainment, 20002012, Greece and EU27

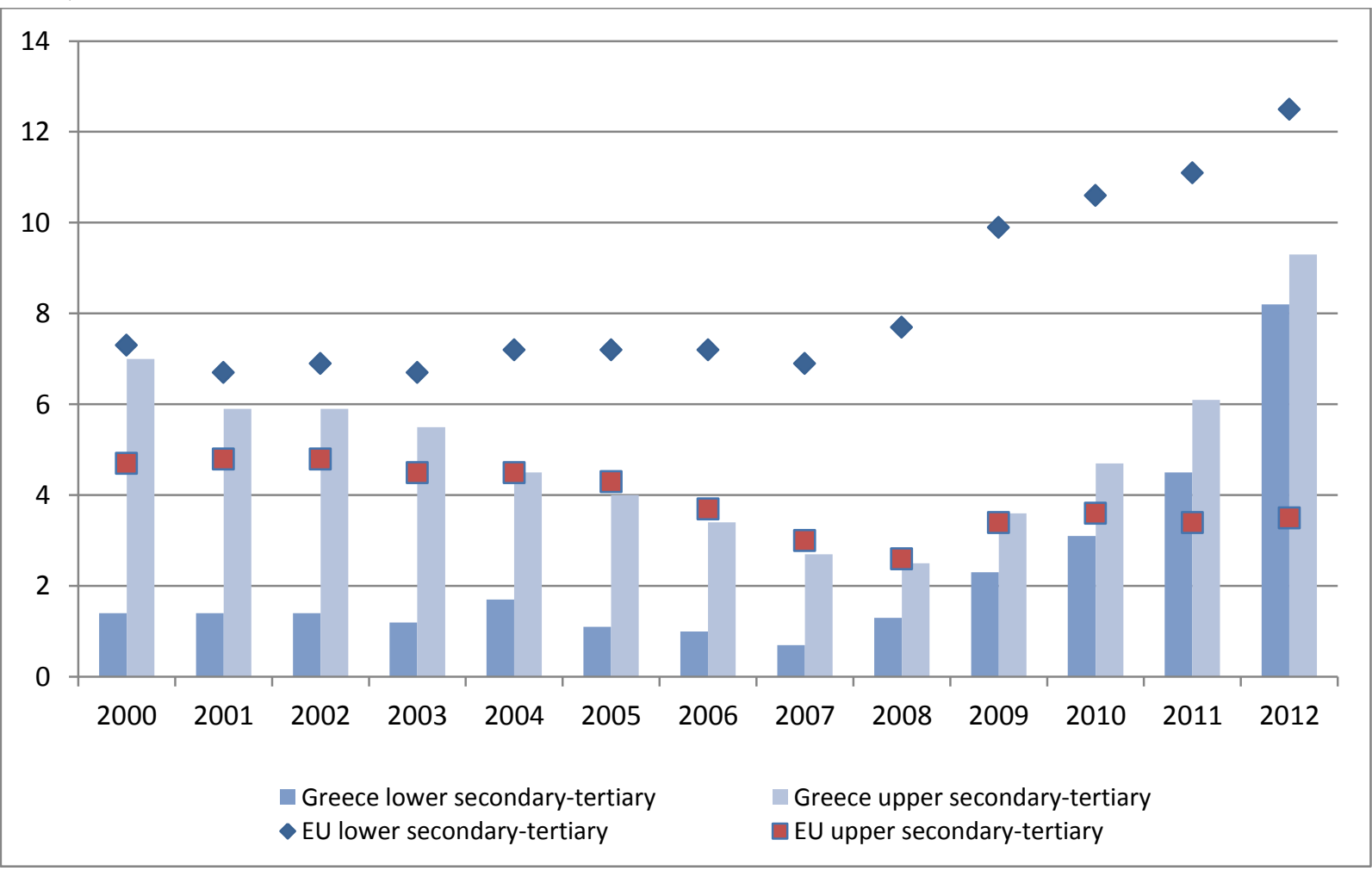

Notes: Eurostat/EU-LFS 
Table 4 Indicators of Labour Market Mismatch, Greece and EU27

(a)

\begin{tabular}{|c|c|c|c|c|c|c|c|c|}
\hline \multirow[t]{2}{*}{ Indicator } & \multicolumn{4}{|c|}{$G R$} & \multicolumn{4}{|c|}{$E \boldsymbol{U}$} \\
\hline & 2012 & $\begin{array}{c}\% \\
\text { change } \\
2000- \\
2007\end{array}$ & $\begin{array}{c}\% \\
\text { change } \\
2007- \\
2012\end{array}$ & $\begin{array}{c}\% \\
\text { change } \\
2000- \\
2012\end{array}$ & 2012 & $\begin{array}{c}\% \\
\text { change } \\
2000- \\
2007\end{array}$ & $\begin{array}{c}\% \\
\text { change } \\
2007- \\
2012\end{array}$ & $\begin{array}{c}\% \\
\text { change } \\
2000- \\
2012\end{array}$ \\
\hline $\begin{array}{l}\text { Unemployment } \\
\text { rate (age 15-64) }\end{array}$ & 24.5 & -3.1 & 16.1 & 13.0 & 10.6 & -2.2 & 3.4 & 1.2 \\
\hline \multicolumn{9}{|c|}{ Unemployment rate by educational attainment (\%) } \\
\hline $\begin{array}{l}\text { - Primary and lower } \\
\text { secondary }\end{array}$ & 26.4 & -1.7 & 18.6 & 16.9 & 18.6 & -1.3 & 7.7 & 6.4 \\
\hline - Upper secondary & 27.5 & -5.3 & 17.7 & 12.4 & 9.6 & -2.6 & 2.6 & 0.0 \\
\hline - Tertiary & 18.2 & -1.0 & 11.1 & 10.1 & 6.1 & -0.9 & 2.1 & 1.2 \\
\hline \multicolumn{9}{|c|}{ Long-term Unemployment rate (\%) } \\
\hline $\begin{array}{l}\text { Long-term } \\
\text { unemployment (12 } \\
\text { months or more) } \\
\text { as \% of total (age } \\
15-64)\end{array}$ & 59.3 & -6.8 & 9.4 & 2.6 & 44.4 & -3.7 & 1.7 & -2 \\
\hline $\begin{array}{l}\text { Long-term } \\
\text { unemployment in } \\
\% \text { of active } \\
\text { population }\end{array}$ & 14.4 & -2.1 & 10.3 & 8.2 & 4.6 & -1.0 & 1.5 & 0.5 \\
\hline $\begin{array}{l}\text { Very long-term } \\
\text { unemployment in } \\
\% \text { of active } \\
\text { population }\end{array}$ & 7.5 & -1.2 & 5.1 & 3.9 & 2.5 & 0.6 & 0.7 & 0.1 \\
\hline \multicolumn{9}{|c|}{ Transition from school to work } \\
\hline $\begin{array}{l}\text { Employment rate } \\
\text { of graduates (age } \\
\text { 20-34) having left } \\
\text { E\&T no more than } \\
3 \text { years before } \\
\text { reference year }\end{array}$ & 42.5 & 8.9 & -25.1 & -11.1 & 74.4 & 4.0 & -5.6 & $-1.6^{\phi}$ \\
\hline
\end{tabular}

(b)

\begin{tabular}{|l|c|c|}
\hline Indicator & $\boldsymbol{G R}$ & $\boldsymbol{E U}$ \\
\hline $\begin{array}{l}\text { Average time (months) between leaving formal } \\
\text { education and starting first significant job (age 15-34) } \\
\left({ }^{\S}\right)\end{array}$ & 13.1 & 6.5 \\
\hline - Primary and lower secondary & 15.1 & 9.9 \\
\hline - Upper secondary & 13.9 & 7.3 \\
\hline - Tertiary & 12.2 & 5.1 \\
\hline Over-qualification rate (\% employees aged 25-64) $\left(^{ \pm}\right)$ & 25.0 & 15.0 \\
\hline $\begin{array}{l}\% \text { of employees with skills higher than needed by } \\
\text { their duties (over-skilling rate) } \\
\left({ }^{g}\right)\end{array}$ & 47.0 & 32.0 \\
\hline $\begin{array}{l}\% \text { of employers with difficulty filling jobs } \\
(\%)\end{array}$ & 38.0 & 35.0 \\
\hline
\end{tabular}

Notes: Eurostat/EU-LFS; Manpower Talent Surveys; 2010 European Survey of Working Conditions; ${ }^{\S} 2009 ;{ }^{ \pm} 2011 ;{ }^{\varnothing}$ 2003-2012; ${ }^{{ }^{9}} 2010 ;{ }^{*} 2013$ 
Table 5 Distribution (\%) of tertiary education graduates by broad occupational group, 2007-2012, Greece and EU27

\begin{tabular}{|l|c|c|c|c|}
\hline & \multicolumn{2}{|c|}{ GR } & \multicolumn{2}{c|}{ EU27 } \\
\hline & 2007 & 2012 & 2007 & 2012 \\
\hline Legislators, senior officials and managers & $9 \%$ & $5 \%$ & $13 \%$ & $10 \%$ \\
\hline Professionals & $53 \%$ & $55 \%$ & $44 \%$ & $49 \%$ \\
\hline Technicians and associate professionals & $17 \%$ & $13 \%$ & $22 \%$ & $20 \%$ \\
\hline Clerical workers & $7 \%$ & $8 \%$ & $8 \%$ & $7 \%$ \\
\hline Service workers and shop and market sales workers & $6 \%$ & $11 \%$ & $5 \%$ & $7 \%$ \\
\hline Skilled agricultural, forestry and fishery workers & $1 \%$ & $1 \%$ & $1 \%$ & $1 \%$ \\
\hline Craft and related trades workers & $2 \%$ & $2 \%$ & $4 \%$ & $2 \%$ \\
\hline Plant and machine operators and assemblers & $1 \%$ & $1 \%$ & $1 \%$ & $1 \%$ \\
\hline Elementary occupations & $1 \%$ & $1 \%$ & $2 \%$ & $2 \%$ \\
\hline
\end{tabular}

Source: Eurostat

Table 6 Determinants of probability of over-qualification in Greece and EU+, 2011, employees, aged 25-64

\begin{tabular}{|c|c|c|}
\hline & GR & $\mathbf{E U +}$ \\
\hline \multirow[t]{2}{*}{ Male } & $-0.010 * *$ & $-0.017 *$ \\
\hline & $(0.005)$ & $(0.010)$ \\
\hline \multicolumn{3}{|l|}{ Age group } \\
\hline \multirow[t]{2}{*}{$-35-44$} & $-0.012 * *$ & $-0.035 * * *$ \\
\hline & $(0.006)$ & $(0.008)$ \\
\hline \multirow[t]{2}{*}{$-45-54$} & $-0.037 * * *$ & $-0.057 * * *$ \\
\hline & $(0.007)$ & $(0.012)$ \\
\hline$-55-64$ & $-0.056 * * *$ & $-0.053 * * *$ \\
\hline (omitted: 25-34) & $(0.009)$ & $(0.011)$ \\
\hline \multirow{2}{*}{ Married } & $-0.013 * *$ & $-0.009 * * *$ \\
\hline & $(0.005)$ & $(0.003)$ \\
\hline \multirow[t]{2}{*}{ Native } & $-0.114 * * *$ & $-0.107 * * *$ \\
\hline & $(0.009)$ & $(0.029)$ \\
\hline \multirow[t]{2}{*}{ Lifelong learning } & $-0.049 * * *$ & $0.011 * *$ \\
\hline & $(0.014)$ & $(0.005)$ \\
\hline \multicolumn{3}{|l|}{ Firm size } \\
\hline \multirow[t]{2}{*}{$-11-49$} & -0.009 & 0.003 \\
\hline & $(0.006)$ & $(0.006)$ \\
\hline$-50+$ & -0.006 & 0.009 \\
\hline (omitted: 0-10) & $(0.007)$ & $(0.007)$ \\
\hline \multirow[t]{2}{*}{ Tenure } & $-0.002 *$ & $-0.001 * * *$ \\
\hline & $(0.001)$ & $(0.000)$ \\
\hline \multirow[t]{2}{*}{ Tenure squared } & $-0.000 * *$ & $-0.000 * *$ \\
\hline & $(0.000)$ & $(0.000)$ \\
\hline \multirow[t]{2}{*}{ Part time work } & $0.101 * * *$ & -0.003 \\
\hline & $(0.016)$ & $(0.008)$ \\
\hline \multirow[t]{2}{*}{ Temporary contract } & $0.014 *$ & 0.001 \\
\hline & $(0.008)$ & $(0.004)$ \\
\hline \multirow[t]{2}{*}{ Supervisory duties } & $-0.056 * * *$ & -0.005 \\
\hline & $(0.007)$ & $(0.009)$ \\
\hline Shift work & $0.038 * * *$ & -0.001 \\
\hline
\end{tabular}




\begin{tabular}{|c|c|c|}
\hline & $(0.006)$ & $(0.010)$ \\
\hline \multirow[t]{2}{*}{ Ln(hours) } & $0.080 * * *$ & -0.010 \\
\hline & $(0.015)$ & $(0.012)$ \\
\hline \multirow[t]{2}{*}{ Moonlighting } & $-0.054 * * *$ & 0.001 \\
\hline & $(0.017)$ & $(0.007)$ \\
\hline \multicolumn{3}{|l|}{ Status last year } \\
\hline \multirow[t]{2}{*}{ Unemployed } & $0.045 * * *$ & $0.011 * * *$ \\
\hline & $(0.015)$ & $(0.004)$ \\
\hline \multirow[t]{2}{*}{ Student } & $0.107 *$ & $0.092 * * *$ \\
\hline & $(0.058)$ & $(0.022)$ \\
\hline Other & 0.012 & $0.015^{* *}$ \\
\hline \multirow{3}{*}{$\begin{array}{l}\text { (omitted: employed) } \\
\text { Proxy respondent }\end{array}$} & $(0.036)$ & $(0.007)$ \\
\hline & $-0.008^{*}$ & $0.006^{* * *}$ \\
\hline & $(0.005)$ & $(0.002)$ \\
\hline \multicolumn{3}{|l|}{ Industry } \\
\hline \multirow[t]{2}{*}{ Agriculture, forestry and fishing } & $0.470 * * *$ & $0.173 * * *$ \\
\hline & $(0.019)$ & $(0.036)$ \\
\hline \multirow[t]{2}{*}{ Manufacturing } & $0.426 * * *$ & $0.164 * * *$ \\
\hline & $(0.016)$ & $(0.021)$ \\
\hline \multirow[t]{2}{*}{ Construction } & $0.574 * * *$ & $0.130 * * *$ \\
\hline & $(0.014)$ & $(0.034)$ \\
\hline \multirow[t]{2}{*}{ Wholesale \& retail trade } & $0.415 * * *$ & $0.174 * * *$ \\
\hline & $(0.016)$ & $(0.029)$ \\
\hline \multirow[t]{2}{*}{ Transportation \& storage } & $0.378 * * *$ & $0.203 * * *$ \\
\hline & $(0.020)$ & $(0.023)$ \\
\hline \multirow[t]{2}{*}{ Accommodation \& food storage } & $0.453 * * *$ & $0.170 * * *$ \\
\hline & $(0.018)$ & $(0.040)$ \\
\hline \multirow[t]{2}{*}{ ICT } & $0.355 * * *$ & $0.121 * * *$ \\
\hline & $(0.023)$ & $(0.026)$ \\
\hline \multirow[t]{2}{*}{ Financial \& insurance activities } & $0.411 * * *$ & $0.251 * * *$ \\
\hline & $(0.019)$ & $(0.031)$ \\
\hline \multirow[t]{2}{*}{ Real estate activities } & $0.445 * * *$ & $0.275^{* * *}$ \\
\hline & $(0.099)$ & $(0.034)$ \\
\hline \multirow[t]{2}{*}{ Professional, scientific \& technical } & $0.234 * * *$ & $0.176^{* * *}$ \\
\hline & $(0.023)$ & $(0.042)$ \\
\hline \multirow[t]{2}{*}{ Administrative \& support services } & $0.541 * * *$ & $0.220 * * *$ \\
\hline & $(0.017)$ & $(0.031)$ \\
\hline \multirow[t]{2}{*}{ Public administration \& defence } & $0.433 * * *$ & $0.220 * * *$ \\
\hline & $(0.015)$ & $(0.031)$ \\
\hline \multirow[t]{2}{*}{ Human health \& social work } & $0.197 * * *$ & $0.125 * * *$ \\
\hline & $(0.019)$ & $(0.027)$ \\
\hline Other & $0.538 * * *$ & $0.197 * * *$ \\
\hline (omitted: Education) & $(0.015)$ & $(0.029)$ \\
\hline Country dummies & - & $\sqrt{ }$ \\
\hline Observations & 40,824 & 910,285 \\
\hline $\begin{array}{l}\text { Notes: Marginal effects of probit est } \\
\mathrm{p}<0.01, * * \mathrm{p}<0.05, * \mathrm{p}<0.1 ; \text { The EU } \\
\text { Ireland and Croatia but including No } \\
\text { Source: European Labour Force Sur }\end{array}$ & $\begin{array}{l}\text { lard errors } \\
\text { group of } 27\end{array}$ & $\begin{array}{l}\text { Intry in EU+ sample; } * * \\
\text { EU28 minus Germany, } \\
\text { own estimations }\end{array}$ \\
\hline
\end{tabular}

Table 7 Determinants of probability of establishments facing difficulties in finding staff for skilled jobs, Greece and EU27, 2009

\begin{tabular}{|l|c|c|}
\hline & GR & EU \\
\hline Casual or atypical workforce & $0.070^{* *}$ & $0.029^{* * *}$ \\
\hline & $(0.036)$ & $(0.005)$ \\
\hline Variable pay & 0.029 & $0.010^{* *}$ \\
\hline & $(0.034)$ & $(0.004)$ \\
\hline High performance workplace practices & 0.022 & $0.016^{* *}$ \\
\hline & $(0.021)$ & $0.006)$ \\
\hline Changes in establishment in last 3 years & 0.023 & $0.022^{* * *}$ \\
\hline & $(0.025)$ & $(0.005)$ \\
\hline Atypical hours & $0.064^{* *}$ & $0.012^{* * *}$ \\
\hline
\end{tabular}




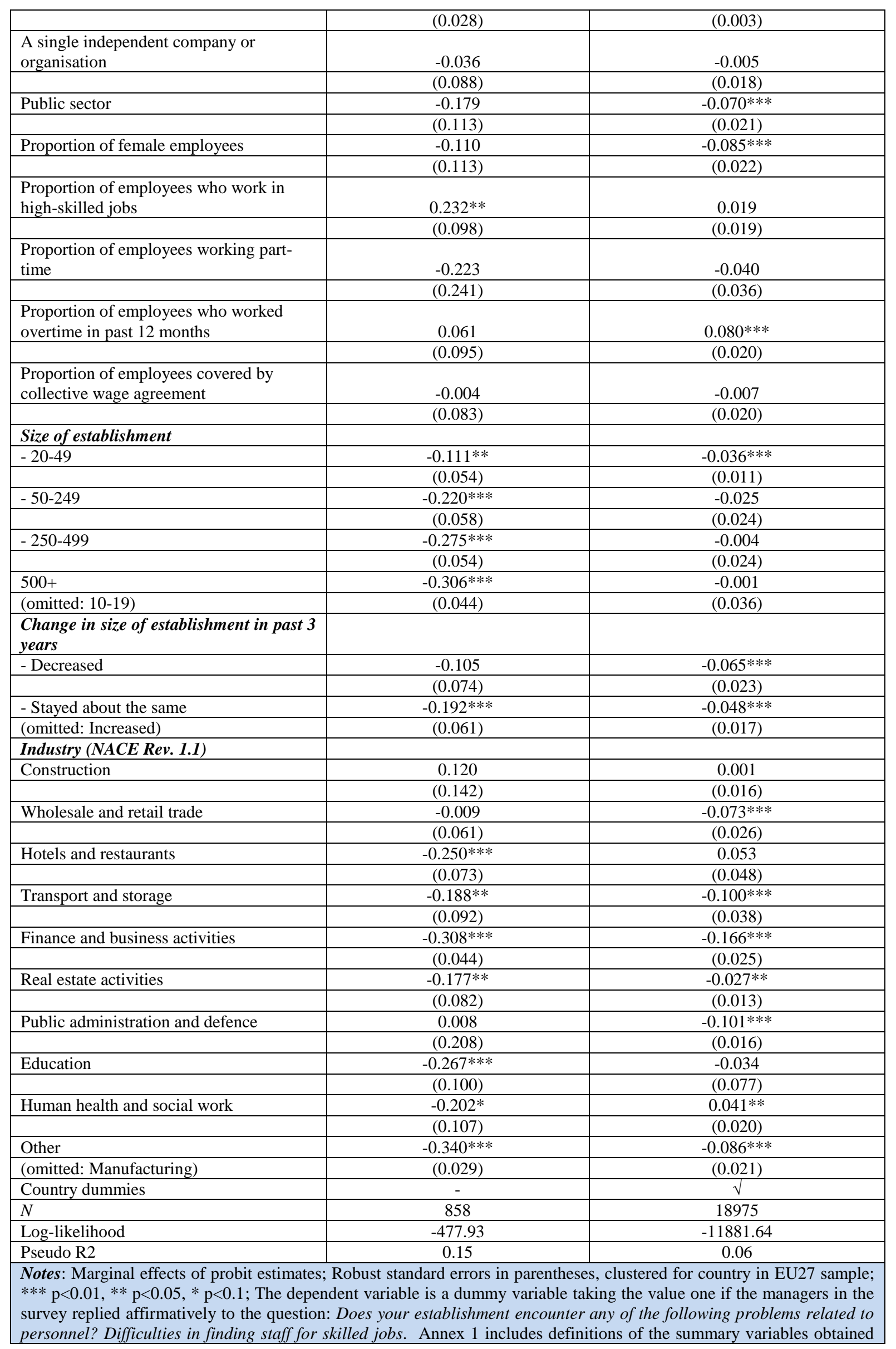


Figure 5: Distribution of active population by level of education and orientation among medium-qualified individuals, Greece and EU27, age 25-34, 2009

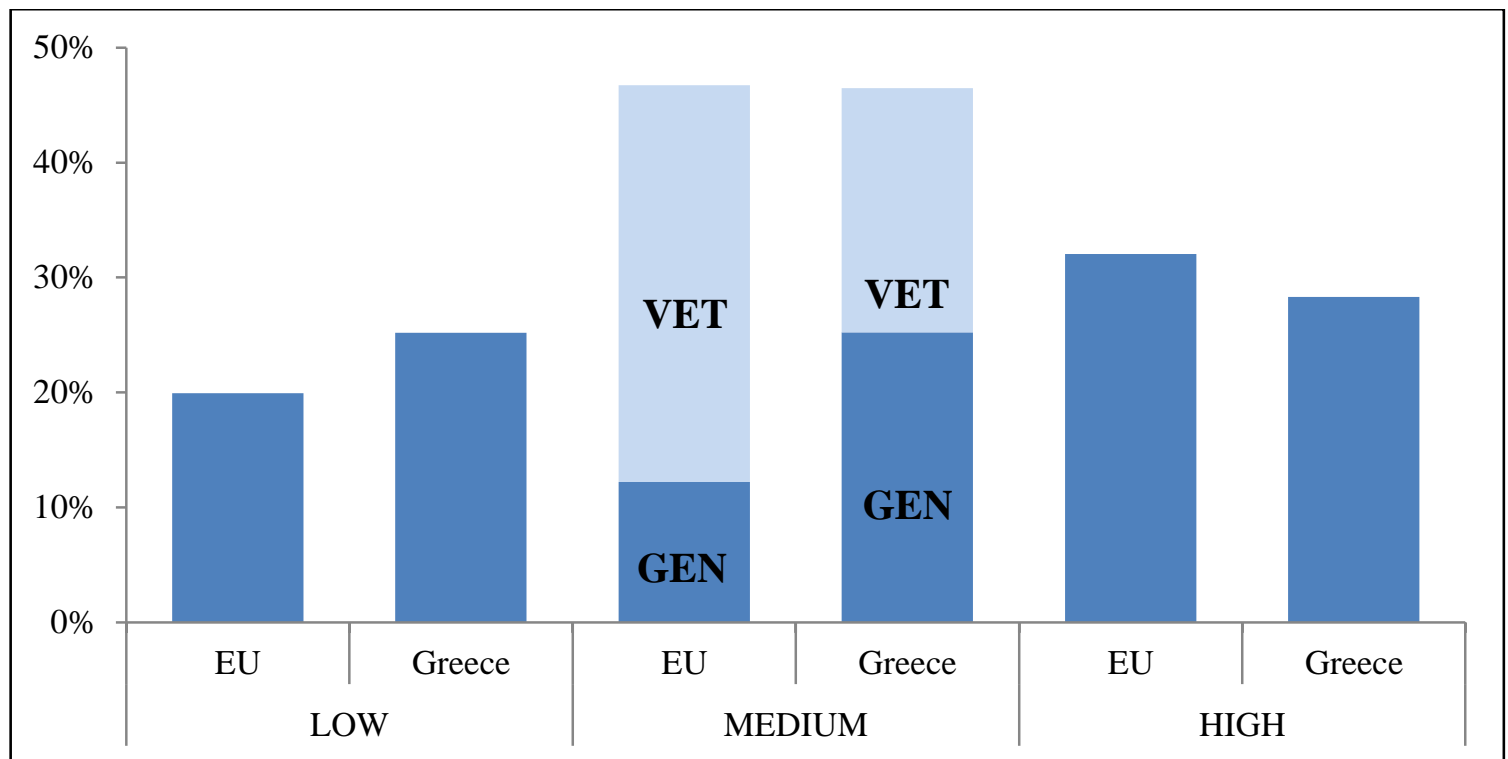

Notes: Low = ISCED 0-2; Medium = ISCED 3-4; High = ISCED 5-6. GEN = general education (defined as less than $25 \%$ of the programme content is vocational); VET = vocational (and pre-vocational) education and training (defined as at least $25 \%$ of the programme content is vocational i.e. oriented towards a specific category of occupations or trades and leading to a labour market relevant qualification)

Source: 2009 EULFS ad hoc module.

Table 8: Attitudes towards vocational education and training, 2011, GR and EU27

\begin{tabular}{|l|c|c|}
\hline$(\%)$ & $G \boldsymbol{E}$ & $\boldsymbol{E U 2 7}$ \\
\hline Have you ever in the past or are you currently taking VET? & 31 & 47 \\
\hline Does VET have a very positive or fairly positive image in your country? & 75 & 71 \\
\hline People in VET learn skills needed by employers & 83 & 82 \\
\hline VET does not prepare people to set up their own business & 35 & 43 \\
\hline In VET people do not learn skills such as communication and teamwork & 25 & 34 \\
\hline VET offers high quality learning & 70 & 75 \\
\hline VET gives access to modern equipment (computers, machines etc) & 71 & 82 \\
\hline Teachers and trainers in VET are competent & 76 & 76 \\
\hline VET enables you to continue with university studies afterwards & 59 & 68 \\
\hline VET leads to jobs which are well-paid & 59 & 55 \\
\hline VET leads to jobs not well regarded in society & 34 & 38 \\
\hline VET leads to professionals highly demanded on the labour market & 73 & 73 \\
\hline VET offers good career opportunities & 64 & 72 \\
\hline VET contributes positively to the economy of your country & 81 & 83 \\
\hline VET is playing a role in reducing unemployment in your country & 72 & 76 \\
\hline VET does not stimulate enough the creation of small companies in your country & 35 & 47 \\
\hline
\end{tabular}


Compared to general secondary or higher education, it is easier to be accepted for VET?

Table 9: VET premiums and labour market outcomes of young medium-qualified adults (age 20-34), GR and EU27, 2009

\begin{tabular}{|l|c|c|c|c|c|c|}
\hline & \multicolumn{2}{|c|}{$(1)$} & \multicolumn{2}{c|}{$(2)$} & \multicolumn{2}{c|}{ (3) } \\
& First job search duration & Probability of employment & \multicolumn{2}{c|}{ Over-qualified in first job } \\
\hline $\begin{array}{l}\text { Medium } \\
\text { VET }\end{array}$ & $0.54 * *$ & $0.49 * *$ & $0.99 * *$ & $0.68 * *$ & $1.80 * *$ & $2.41^{* *}$ \\
\hline $\begin{array}{l}\text { Medium } \\
\text { General }\end{array}$ & $0.41^{* *}$ & $0.22 * *$ & $0.72 * *$ & 0.14 & $2.07 * *$ & 0.14 \\
\hline $\begin{array}{l}\text { Difference } \\
\text { VET- } \\
\text { General) }\end{array}$ & $0.13^{* *}$ & $0.27 * *$ & $0.27 * *$ & $0.53 * *$ & $-0.27 * *$ & $2.27 *$ \\
\hline $\mathrm{N}$ & 90923 & 7240 & 170495 & 9321 & 73983 & 2988 \\
\hline
\end{tabular}

Notes: Estimates based on 2009 EULFS ad hoc module. $* \mathrm{p}<0.05$, $* * \mathrm{p}<0.01$. The figures reported in column (1) are estimates of a survival model, namely log hazard ratios assuming a Weibull distribution of first job search duration (in months). Higher positive coefficients indicate a faster transition to work (shorter first job search duration). Column (2): multinomial logit estimates of the probability of being currently employed (as opposed to inactive). Column (3) are multinomial logit estimates of over-qualification (reference group: matched). Heteroskedasticity robust standard errors. The set of regressors includes country dummy variables and individual-level controls (gender, age, marital status, foreigner, parents with degree, children in the household, number of children). The robustness of the estimates is confirmed when only individuals who have completed formal education are included in the analysis. In all columns the reference (omitted) group for educational level is ISCED 0-2.

Source: CEDEFOP (2013)

Table 10: Indicators of skill requirements, Greece and EU

\begin{tabular}{|c|c|c|c|c|}
\hline Panel A & $G R$ & & EU27 & \\
\hline & 2005 & 2010 & 2005 & 2010 \\
\hline $\begin{array}{l}\text { New processes or technologies } \\
\text { introduced in last } 3 \text { years in } \\
\text { workplace }\end{array}$ & - & 33.3 & - & 42.5 \\
\hline $\begin{array}{l}\% \text { of time main job involves } \\
\text { working with computers }\end{array}$ & 27.6 & 37.5 & 38.0 & 41.0 \\
\hline Job involves monotonous tasks & 57.7 & 53.3 & 43.8 & 45.5 \\
\hline Job involves complex tasks & 55.4 & 53.7 & 60.3 & 57.9 \\
\hline Job involves learning new things & 64.9 & 52.5 & 69.7 & 68.2 \\
\hline Able to choose order of tasks & 47.4 & 44.1 & 58.5 & 62.0 \\
\hline Able to choose methods of work & 48.0 & 48.6 & 63.0 & 63.4 \\
\hline Able to choose speed of work & 65.3 & 59.7 & 63.0 & 66.2 \\
\hline $\begin{array}{l}\text { Able to apply own ideas at work } \\
\text { (most of the time/always) }\end{array}$ & 42.6 & 37.5 & 52.85 & 50.4 \\
\hline \multicolumn{5}{|l|}{$\begin{array}{l}\text { Undergone training in past } 12 \\
\text { months to improve skills }\end{array}$} \\
\hline $\begin{array}{l}\text { - Paid for or provided by } \\
\text { employer or self if self-employed }\end{array}$ & 18.4 & 17.0 & 29.3 & 37.0 \\
\hline - Paid for by yourself & 5.6 & 5.6 & 4.9 & 6.4 \\
\hline - On the job training & 22.2 & 21.1 & 29.9 & 36.5 \\
\hline $\begin{array}{l}\% \text { of employees not very/not at } \\
\text { all satisfied with job }\end{array}$ & 35.1 & 32.6 & 17.5 & 15.6 \\
\hline $\begin{array}{l}\% \text { of employees agree/strongly } \\
\text { agree are well-paid for work they } \\
\text { do }\end{array}$ & 35.0 & 33.8 & 43.5 & 41.2 \\
\hline
\end{tabular}




\begin{tabular}{|c|c|c|c|c|}
\hline $\begin{array}{l}\% \text { of employees agree/strongly } \\
\text { agree job offers good career } \\
\text { prospects }\end{array}$ & 30.1 & 29.9 & 31.5 & 31.4 \\
\hline $\begin{array}{l}\% \text { of employees agree/strongly } \\
\text { agree that organisation motivates } \\
\text { them to give their best } \\
\text { performance }\end{array}$ & - & 55.9 & - & 60.0 \\
\hline \multirow[t]{2}{*}{ Panel B } & GR & & $E U 25$ & \\
\hline & 2004 & 2010 & 2004 & 2010 \\
\hline $\begin{array}{l}\% \text { it is quite true/very true there is } \\
\text { a lot of variety in work }\end{array}$ & 59.2 & 52.1 & 68.9 & 65.2 \\
\hline $\begin{array}{l}\% \text { it is quite true/very true current } \\
\text { job requires learning new things }\end{array}$ & 59.1 & 59.4 & 62.2 & 59.3 \\
\hline $\begin{array}{l}\% \text { agree/strongly agree current } \\
\text { job requires work very hard }\end{array}$ & 54.5 & 65.9 & 62.0 & 69.1 \\
\hline $\begin{array}{l}\text { \% agree/strongly agree } \\
\text { opportunities for advancement } \\
\text { are good in current job }\end{array}$ & 31.4 & 35.1 & 30.1 & 32.4 \\
\hline
\end{tabular}

Source: Panel (A) includes means obtained from a sample of adult employees from the $4^{\text {th }}$ and $5^{\text {th }}$ waves of the European Working Conditions Surveys; Panel (B) contains means from a sample of adult employees from rounds 2 and 5 of the European Social Surveys. 


\section{Annex 1 Details of factor analysis}

Factor analysis finds few common factors that linearly reconstruct a set of identified variables. In the analysis conducted in this paper using data from the $2^{\text {nd }}$ European Company Survey, five variable groupings are used to identify a set of common factors. These groupings are:

Group 1: Casual or atypical workforce,

Group 2: Variable pay,

Group 3: High performance workplace practices,

Group 4: Changes in establishment in last 3 years,

Group 5: Atypical hours,

For each grouping, a principal-component factor analysis determined the number of vectors to be retained. In all cases, this was taken to be those factors with an Eigen value greater than 1.

\begin{tabular}{|c|c|c|c|c|}
\hline Groupings & Variables & Eigenvalues & Proportion & Cumulative \\
\hline \multirow[t]{3}{*}{$\begin{array}{l}\text { Casual or atypical } \\
\text { workforce }\end{array}$} & Temporary agency workers have been in company & 2.08 & 0.52 & 0.52 \\
\hline & Staff with fixed term contracts have been in company & 1.09 & 0.27 & 0.79 \\
\hline & Freelances have been in company & 0.84 & 0.21 & 1.00 \\
\hline \multirow[t]{3}{*}{ Variable pay } & Employees receive performance-related pay & 1.32 & 0.44 & 0.44 \\
\hline & Profit sharing scheme offered in establishment & 0.89 & 0.30 & 0.73 \\
\hline & Share ownership scheme offered in establishment & 0.80 & 0.27 & 1.00 \\
\hline \multirow[t]{5}{*}{$\begin{array}{l}\text { High performance } \\
\text { workplace practices }\end{array}$} & $\begin{array}{l}\text { Employees can adapt - within certain limits - the time when } \\
\text { they begin or finish their daily work according to their } \\
\text { personal needs or wishes }\end{array}$ & 1.51 & 0.30 & 0.30 \\
\hline & Work in teams is important & 0.94 & 0.19 & 0.49 \\
\hline & $\begin{array}{l}\text { A person or committee is in charge or representing employees } \\
\text { in issues of safety and health at work }\end{array}$ & 0.93 & 0.19 & 0.68 \\
\hline & Need for training is periodically checked in a systematic way & 0.90 & 0.18 & 0.86 \\
\hline & Employees given time off normal duties for training & 0.72 & 0.14 & 1.00 \\
\hline \multirow[t]{4}{*}{$\begin{array}{l}\text { Changes in } \\
\text { establishment in last } \\
3 \text { years }\end{array}$} & Major changes in remuneration system & 1.80 & 0.45 & 0.45 \\
\hline & Changes in the organisation of the work process & 0.84 & 0.21 & 0.66 \\
\hline & Changes in the working time arrangements & 0.77 & 0.19 & 0.85 \\
\hline & Restructuring measures & 0.59 & 0.15 & 1.00 \\
\hline \multirow[t]{4}{*}{ Atypical hours } & Employees regularly required to work on Saturdays & 2.59 & 0.65 & 0.65 \\
\hline & Employees regularly required to work on Sundays & 0.71 & 0.18 & 0.82 \\
\hline & Employees required to work in a shift system or comparable & 0.44 & 0.11 & 0.93 \\
\hline & Employees required to work at night between $11 \mathrm{pm}-6 \mathrm{am}$ & 0.27 & 0.07 & 1.00 \\
\hline
\end{tabular}




\section{Annex 2 Descriptive Statistics}

\begin{tabular}{|c|c|c|}
\hline \multicolumn{3}{|c|}{$\begin{array}{l}\text { Table A2(a) Descriptive statistics (mean, standard deviation), Greece and EU+, 2011, } \\
\text { employees, aged 25-64 }\end{array}$} \\
\hline & GR & $\mathbf{E U}+$ \\
\hline Male & $0.56(0.50)$ & $0.52(0.50)$ \\
\hline \multicolumn{3}{|l|}{ Age group } \\
\hline$-25-34$ & $0.30(0.46)$ & $0.28(0.45)$ \\
\hline$-35-44$ & $0.35(0.47)$ & $0.31(0.46)$ \\
\hline$-45-54$ & $0.26(0.44)$ & $0.28(0.45)$ \\
\hline$-55-64$ & $0.09(0.29)$ & $0.14(0.34)$ \\
\hline Married & $0.65(0.48)$ & $0.60(0.49)$ \\
\hline Native & $0.88(0.33)$ & $0.92(0.26)$ \\
\hline Lifelong learning & $0.02(0.15)$ & $0.11(0.32)$ \\
\hline \multicolumn{3}{|l|}{ Firm size } \\
\hline$-0-10$ & $0.35(0.48)$ & $0.18(0.38)$ \\
\hline$-11-49$ & $0.27(0.44)$ & $0.29(0.45)$ \\
\hline$-50+$ & $0.18(0.38)$ & $0.43(0.50)$ \\
\hline Tenure & $11.88(9.35)$ & $11.07(9.86)$ \\
\hline Tenure squared & $217.44(295.0)$ & $219.73(343.6)$ \\
\hline Part time work & $0.06(0.24)$ & $0.17(0.37)$ \\
\hline Temporary contract & $0.11(0.31)$ & $0.11(0.31)$ \\
\hline Supervisory duties & $0.11(0.32)$ & $0.23(0.42)$ \\
\hline Shift work & $0.21(0.40)$ & $0.17(0.38)$ \\
\hline Usual weekly hours & $39.04(8.74)$ & $36.94(10.05)$ \\
\hline Moonlighting & $0.02(0.13)$ & $0.04(0.20)$ \\
\hline Proxy respondent & $0.56(0.50)$ & $0.70(0.46)$ \\
\hline \multicolumn{3}{|l|}{ Status last year } \\
\hline - Employed & $0.97(0.17)$ & $0.94(0.24)$ \\
\hline - Unemployed & $0.026(0.16)$ & $0.03(0.18)$ \\
\hline - Student & $0.00(0.04)$ & $0.01(0.09)$ \\
\hline - Other & $0.00(0.06)$ & $0.02(0.14)$ \\
\hline \multicolumn{3}{|l|}{ Industry } \\
\hline Agriculture, forestry and fishing & $0.02(0.14)$ & $0.02(0.13)$ \\
\hline Manufacturing & $0.15(0.35)$ & $0.19(0.40)$ \\
\hline Construction & $0.06(0.27)$ & $0.06(0.25)$ \\
\hline Wholesale \& retail trade & $0.16(0.37)$ & $0.13(0.33)$ \\
\hline Transportation \& storage & $0.05(0.32)$ & $0.06(0.23)$ \\
\hline Accommodation \& food storage & $0.06(0.24)$ & $0.04(0.19)$ \\
\hline ICT & $0.03(0.16)$ & $0.03(0.17)$ \\
\hline Financial \& insurance activities & $0.04(0.20)$ & $0.04(0.18)$ \\
\hline Real estate activities & $0.00(0.02)$ & $0.01(0.09)$ \\
\hline Professional, scientific \& technical & $0.03(0.17)$ & $0.04(0.20)$ \\
\hline Administrative \& support services & $0.02(0.15)$ & $0.04(0.19)$ \\
\hline Public administration \& defence & $0.12(0.33)$ & $0.08(0.28)$ \\
\hline Education & $0.11(0.32)$ & $0.09(0.29)$ \\
\hline Human health \& social work & $0.08(0.27)$ & $0.12(0.32)$ \\
\hline Other & $0.06(0.23)$ & $0.05(0.22)$ \\
\hline \multicolumn{3}{|c|}{$\begin{array}{l}\text { Source: European Labour Force Survey microdata; The EU+ sample is comprised of a group of } 27 \text { European countries, } \\
\text { namely the EU } 28 \text { minus Germany, Ireland and Croatia but including Norway and Switzerland. Appropriate weighting } \\
\text { applied (COEFF). }\end{array}$} \\
\hline
\end{tabular}




\begin{tabular}{|c|c|c|}
\hline \multicolumn{3}{|c|}{$\begin{array}{l}\text { Table A2(b) Descriptive statistics (mean, standard deviation), establishments, Greece } \\
\text { and EU27, } 2009\end{array}$} \\
\hline & GR & EU27 \\
\hline Casual or atypical workforce & $-0.85(0.75)$ & $-0.23(1.31)$ \\
\hline Variable pay & $-0.43(0.73)$ & $-0.12(1.06)$ \\
\hline High performance workplace practices & $-1.07(1.40)$ & $-0.12(1.25)$ \\
\hline Changes in establishment in last 3 years & $-0.44(1.22)$ & $-0.12(1.30)$ \\
\hline Atypical hours & $-0.53(1.28)$ & $-0.33(1.44)$ \\
\hline $\begin{array}{l}\text { A single independent company or } \\
\text { organisation }\end{array}$ & $0.88(0.32)$ & $0.69(0.46)$ \\
\hline Public sector & $0.20(.40)$ & $0.20(0.40)$ \\
\hline Proportion of female employees & $0.49(0.29)$ & $0.46(0.31)$ \\
\hline $\begin{array}{l}\text { Proportion of employees who work in high- } \\
\text { skilled jobs }\end{array}$ & $0.38(0.35)$ & $0.25(0.30)$ \\
\hline Proportion of employees working part-time & $0.06(0.16)$ & $0.15(0.23)$ \\
\hline $\begin{array}{l}\text { Proportion of employees who worked } \\
\text { overtime in past } 12 \text { months }\end{array}$ & $0.14(0.26)$ & $0.32(0.36)$ \\
\hline $\begin{array}{l}\text { Proportion of employees covered by } \\
\text { collective wage agreement }\end{array}$ & $0.78(0.37)$ & $0.63(0.46)$ \\
\hline \multicolumn{3}{|l|}{ Size of establishment } \\
\hline$-10-19$ & $0.69(0.46)$ & $0.52(0.49)$ \\
\hline$-20-49$ & $0.23(0.42)$ & $0.30(0.45)$ \\
\hline$-50-249$ & $0.06(0.24)$ & $0.14(0.35)$ \\
\hline$-250-499$ & $0.01(0.08)$ & $0.01(0.12)$ \\
\hline $500+$ & $0.00(0.06)$ & $0.00(0.09)$ \\
\hline \multicolumn{3}{|l|}{$\begin{array}{l}\text { Change in size of establishment in past } 3 \\
\text { years }\end{array}$} \\
\hline - Increased & $0.38(0.48)$ & $0.32(0.46)$ \\
\hline - Decreased & $0.16(0.36)$ & $0.23(0.42)$ \\
\hline - Stayed about the same & $0.45(0.49)$ & $0.43(0.49)$ \\
\hline \multicolumn{3}{|l|}{ Industry (NACE Rev. 1.1) } \\
\hline - Manufacturing & $0.21(0.41)$ & $0.19(0.39)$ \\
\hline - Construction & $0.01(0.11)$ & $0.08(0.27)$ \\
\hline - Wholesale and retail trade & $0.25(0.43)$ & $0.19(0.39)$ \\
\hline - Hotels and restaurants & $0.04(0.19)$ & $0.04(0.20)$ \\
\hline - Transport and storage & $0.03(0.17)$ & $0.04(0.21)$ \\
\hline - Finance and business activities & $0.00(0.07)$ & $0.02(0.15)$ \\
\hline - Real estate activities & $0.07(0.25)$ & $0.12(0.32)$ \\
\hline - Public administration and defence & $0.08(0.27)$ & $0.05(0.22)$ \\
\hline - Education & $0.13(0.34)$ & $0.09(0.29)$ \\
\hline - Human health and social work & $0.13(0.34)$ & $0.08(0.27)$ \\
\hline - Other & $0.00(0.09)$ & $0.05(0.23)$ \\
\hline
\end{tabular}

